\title{
Effects of Cocaine in Rats Exposed to Heroin
}

\author{
Francesco Leri*,', Joseph Flores ${ }^{2}$, Heshmat Rajabi ${ }^{3}$ and Jane Stewart ${ }^{3}$ \\ 'Department of Psychology, University of Guelph, Canada; ${ }^{2}$ Department of Neuroscience, University of British Columbia, Canada; ${ }^{3}$ Center for \\ Studies in Behavioral Neurobiology, Concordia University, Canada
}

\begin{abstract}
We investigated whether chronic exposure to heroin alters responses to cocaine in ways that might explain the use of cocaine by opioid addicts. To this end, the effects of cocaine $(5$ and $20 \mathrm{mg} / \mathrm{kg}$ ) were assessed on locomotor activity of rats chronically exposed to heroin (0.0, 3.5, 7.0, and $14.0 \mathrm{mg} / \mathrm{kg} /$ day, over 14 days, via osmotic mini-pumps), or withdrawn from heroin ( I day, acute withdrawal, and I4 days, protracted withdrawal). Chronic heroin exposure, in itself, dose dependently increased locomotion and acute cocaine administration further elevated locomotor activity in a dose-dependent and additive manner. During acute withdrawal, there was a dosedependent decrease in locomotion that was reversed by cocaine in a dose-dependent manner. During protracted withdrawal, spontaneous locomotion normalized, but rats previously exposed to heroin displayed cross-sensitization to cocaine as indicated by small, but significant, enhanced locomotor response to $5 \mathrm{mg} / \mathrm{kg}$ of cocaine, and enhanced intravenous self-administration of low doses of cocaine ( $0.13 \mathrm{mg} / \mathrm{kg} /$ infusion). In a separate study, we measured extracellular dopamine (DA) in the nucleus accumbens (Acb) using in vivo microdialysis before and after acute withdrawal from heroin. During chronic exposure to heroin, basal extracellular DA was elevated dose dependently, whereas in acute withdrawal, levels were not different from those in vehicle-treated rats. In response to cocaine, however, DA activity in the Acb was significantly lower in rats withdrawn from the highest dose of heroin.

Neuropsychopharmacology (2003) 28, 2 I02-2I 16, advance online publication, 10 September 2003; doi: I 0.1038/sj.npp. I 300284
\end{abstract}

Keywords: heroin; cocaine; locomotion; self-administration; dopamine; rat

\section{INTRODUCTION}

The use of cocaine by opioid addicts is common and its impact on health hazardous. Co-use of opioid drugs and cocaine has been documented in a number of countries and its prevalence is found to be high both in untreated individuals and in individuals in methadone maintenance (see Leri et al, 2002 for a review). The negative health and social consequences of cocaine use by opioid-dependent individuals are severe, particularly when cocaine is used intravenously (Bux et al, 1995; Schottenfeld et al, 1993; Grella et al, 1997; Hausser et al, 1999; Hudgins et al, 1995; Perez et al, 1997; Schutz et al, 1994). In fact, because of its short half-life, the frequency of injection is high (Bux et al, 1995; Hudgins et al, 1995; Joe and Simpson, 1995). Frequent injections and sharing of syringes (Grella et al, 1995; Hudgins et al, 1995; Joe and Simpson, 1995; Dolan et al, 1987) increase the risk of contracting HIV or other bloodborne infectious diseases (Bickel and Kelly, 1988; Hudgins et al, 1995; Joe and Simpson, 1995; Rowlett et al, 1997; Torrens et al, 1991). In addition, cocaine use, whether

*Correspondence: Francesco Leri, Department of Psychology, University of Guelph, Guelph (ON), NIG 2WI, Canada, Tel: (519) 8244I20, Ext 58264, Fax: (519) 837-8629, E-mail: fleri@uoguelph.ca Received II February 2003; revised 01 June 2003; accepted 03 June 2003

Online publication: I5 July 2003 at http://www.acnp.org/citations/ Npp7| 50303063/default.pdf intravenous or smoked in the form of crack, inevitably makes the drug habit more expensive (Hunt et al, 1984; Strug et al, 1985) leading to income-generating strategies that often include crime (Bickel and Kelly, 1988; Grella et al, 1997; Strug et al, 1985) and sex trade (Grella et al, 1995; Joe and Simpson, 1995). Finally, it has been reported that cocaine-using opioid addicts are more likely to drop out of treatment programs and to relapse (Downey et al, 2000; Perez et al, 1997; Dolan et al, 2001; Broers et al, 2000).

It is important, therefore, to understand the basis of cocaine use in opioid-dependent individuals. One way to explore this issue is to determine whether some patterns of heroin and cocaine co-use are particularly common. Thus, pharmacological reasons motivating co-use could be inferred from particular patterns of coadministration. For example, if heroin and cocaine were found to be preferentially self-administered simultaneously, such as in the form of a 'speedball' (Kosten et al, 1987), it could be inferred that their combination has special pharmacological effects not achievable by the administration of either drug alone (Leri et al, 2002). Or, consistent heroin use following binges of cocaine for example, would suggest that heroin is used to antagonize cocaine-induced hyperstimulation (Kreek, 1997). It is not clear, however, whether a 'most' typical pattern of co-use actually exists, and experimental evidence relating to this issue is scarce (Leri et al, 2003; Benswick et al, 2001; Kidorf and Stitzer, 1993). Furthermore, a pattern 
of co-use may reflect regional means of drug administration (Diaz et al, 1994; Gossop et al, 2000) determined by nonpharmacological factors such as socioeconomical status (Crofts et al, 1996; Dunn and Laranjeira, 1999), age (Carneiro et al, 1999; Griffiths et al, 1992; Dinwiddie et al, 1996), or gender (Doherty et al, 2000; Benswick et al, 2001). Thus, it is very difficult to study the pharmacological basis of co-use of heroin and cocaine by analyzing patterns of use at the population level. An alternative strategy is to ask the users directly, but subjective reports can be difficult to interpret. For example, Gelkopf et al (1999) asked a group of methadone-maintained patients their reasons for cousing benzodiazepines. The responses ranged from 'to relax and induce sleep,' which is consistent with the known psychopharmacolgical action of benzodiazepines, to 'wakeup,' which is not. Therefore, given these difficulties, we reasoned that the pharmacological basis of cocaine use in opioid addicts could be studied in laboratory animals, a strategy that allows for the testing of specific pharmacological hypotheses, while controlling for the confounding impact of social and economical variables.

In the experiments reported here, we studied the effects of cocaine in rats at different stages of heroin exposure, namely: dependence, acute withdrawal, and protracted withdrawal. These stages were selected with the goal of modeling the major pharmacological states associated with heroin addiction in humans (Goldstein, 1972). In these experiments, rats were made dependent by continuous, chronic exposure via osmotic mini-pumps, although it is recognized that this form of administration does not model that used by heroin addicts who typically administer heroin repeatedly over the day (Kreek, 2000). Nevertheless, this method allowed us to assess the stimulatory effects of cocaine at different stages of dependence in rats, during chronic heroin exposure, during spontaneous withdrawal from heroin induced by removal of the mini-pumps, and during protracted withdrawal. Furthermore, using the paradigm of intravenous self-administration, we determined whether sensitivity to the reinforcing properties of cocaine was altered in animals with a history of chronic heroin exposure. Finally, although the link between the reinforcing properties of drugs of abuse and dopaminergic (DA) activity in the mesolimbic DA system is well established (Robinson and Berridge, 2003; Robbins and Everitt, 1999), relatively little is known about DA activity during continuous exposure to heroin, or during acute spontaneous withdrawal. Thus, we used the technique of in vivo microdialysis to assess extracellular levels of DA in the nucleus accumbens (Acb) during chronic heroin exposure, during acute withdrawal, and after a cocaine injection given to animals in acute heroin withdrawal.

\section{MATERIALS AND METHODS}

\section{Subjects}

Male Long-Evans rats (300-350 g, Charles River, QC) served as subjects. They were housed in a colony room on a reverse light-dark cycle (lights on 1900, light off 0800) and had free access to food and water at all times. All behavioral testing occurred between 0900 and 1700. The experimental procedures followed the guidelines of the Canadian Council on Animal Care and were approved by the Animal Care Committee (Concordia University).

\section{Surgeries}

Osmotic mini-pumps. Chronic heroin exposure was achieved by implanting heroin-filled osmotic mini-pumps (s.c.). Thus, rats were anesthetized with isoflurane and a small incision was made in the skin between the scapulae. Using a hemostat, a small pocket was formed by spreading the subcutaneous connective tissues apart. Osmotic minipumps (Alzet model 2002; $0.5 \mu \mathrm{l}$ per hour for 14 days, Durect Corporation, Cupertino, CA) were inserted into the pocket with the flow moderator pointing away from the incision. The skin incision was closed with wound clips. Using the same protocol for anesthesia, the pumps were removed upon completion of the delivery duration.

Intravenous catheterization. Some heroin-exposed rats were prepared with intravenous silastic catheters (Dow Corning, Midland, MI) in the right jugular vein, under sodium pentobarbital anesthesia $(65 \mathrm{mg} / \mathrm{kg}$ i.p., MTC Pharmaceutical, Cambridge, $\mathrm{ON})$. Just before surgery, rats were given atropine sulfate $(0.6 \mathrm{mg} / \mathrm{ml} ; 0.3 \mathrm{ml} / \mathrm{rat}$ s.c., MTC Pharmaceutical, Cambridge, $\mathrm{ON}$ ) and were given Penicillin B (300 $000 \mathrm{IU}, 0.2 \mathrm{ml} /$ rat i.m., Wyeth-Ayerst, Montreal, QC) right after surgery. The catheter was secured to the vein with silk sutures and was passed subcutaneously to the top of the skull where it exited into a connector (a modified 22 gauge cannula; Plastics One, Roanoke, VA) mounted to the skull with jeweler's screws and dental cement. A plastic blocker was placed over the opening of the connector during the recovery period and at all other times when the rats were not in a self-administration session. To prevent clogging, the catheters were flushed daily with saline and every third day with $0.1 \mathrm{ml}$ of a saline-heparin solution (15 IU/ml heparin, ICN Biochemicals, Cleveland, $\mathrm{OH}$ ).

Intracranial cannulation. For the microdialysis experiment, a guide cannula (22 gauge; Plastics One, Roanoke, VA) was implanted in the Acb of the right hemisphere, under sodium pentobarbital anesthesia (65 mg/kg i.p., MTC Pharmaceutical, Cambridge, $\mathrm{ON}$ ). Just before surgery, rats were given atropine sulfate $(0.6 \mathrm{mg} / \mathrm{ml} ; 0.3 \mathrm{ml} /$ rat s.c., MTC Pharmaceutical, Cambridge, ON). With the arm of the stereotaxic inclined at a $10^{\circ}$ angle, and the head of the rat positioned at a $5^{\circ}$ degree angle, the coordinates used were: $\mathrm{AP}+3.4 \mathrm{~mm}, \mathrm{ML}+2.5 \mathrm{~mm}$, and $\mathrm{DV}-6.2 \mathrm{~mm}$ (Paxinos and Watson, 1997). Animals were allowed at least 8 days of recovery from surgery before testing.

\section{Histology}

At the end of the microdialysis experiment, animals were perfused transcardially with $10 \%$ formal hydrate-saline solution under chloral hydrate $(400 \mathrm{mg} / \mathrm{kg})$ anesthesia. The brains were removed and further fixed in a $10 \%$ formal-saline and 25\% sucrose solution for at least $24 \mathrm{~h}$ before sectioning. Brains were sectioned at $30 \mu \mathrm{m}$, and every other section through the Acb was mounted and stained with Cresyl Violet. Data from individual subjects were 
discarded if the microdialysis probe was positioned beyond the boundaries of the intended site.

\section{Apparatus}

Locomotion chambers. Locomotor activity was monitored in a bank of 12 activity boxes. Each box $\left(20 \times 41 \times 25 \mathrm{~cm}^{3}\right)$ was constructed of white pressed wood (rear and two side walls), a wire screen ceiling, a Plexiglas front hinged door, and a tubular stainless-steel floor. Two photo-cells, positioned $3.5 \mathrm{~cm}$ above the floor and spaced evenly along the longitudinal axis of each box, were used to estimate horizontal locomotion. The activity boxes were kept in a room dimly lit with red lights, and they were controlled by a computer located in an adjacent room, running a custommade software.

Self-administration chambers. In all, 18 Plexiglas operant chambers $\left(27 \times 27 \times 27 \mathrm{~cm}^{3}\right.$, custom-made, Concordia University) were used in the self-administration experiment. Each chamber was enclosed in a larger $\left(87 \times 54 \times 43 \mathrm{~cm}^{3}\right.$, custom-made, Concordia University) sound-attenuating plywood chamber. Each operant box had two levers (Med Associates, Lafayette, IN), one retractable and one stationary, located $10 \mathrm{~cm}$ apart and $10 \mathrm{~cm}$ above the floor of the box. The retractable lever (active lever) was connected to an infusion pump for the delivery of drugs (Razel Scientific Instruments, Stamford, CT), which was positioned outside the sound-insulating chamber. The stationary lever served to control for baseline, nonreinforced, operant behavior; depression of this lever had no consequences (inactive lever), but all presses were recorded. There was a white light stimulus $3 \mathrm{~cm}$ above the active lever that came on for $30 \mathrm{~s}$ at the beginning of the session, and for the duration of each drug infusion, thus serving as a discrete conditioned stimulus (CS) for drug delivery. Throughout the experiment, each self-administration session was started by the activation of a red house light that remained on for the duration of the session.

Microdialysis. Microdialysis was conducted in four hexagonal chambers $\left(42 \times 39 \times 33.5 \mathrm{~cm}^{3}\right.$, custom-made, Concordia University) built from Plexiglas with wooden ceilings and stainless-steel grid floors. The cages were individually housed in wooden cubicles and lighting was provided on a reverse cycle by overhead light bulbs.

The dialysis probe consisted of a $2.2 \mathrm{~mm}$ length of semipermeable dialysis membrane (Fisher Scientific, $240 \mu \mathrm{m}$ OD, $13000 \mathrm{MW}$ cutoff), closed at one end and attached to a $21 \mathrm{~mm}$ long, 26 gauge stainless-steel tubing. A $40-50 \mathrm{~cm}$ long piece of PE tubing connected the other end of the stainless-steel shaft to a single channel liquid swivel stationed above the testing chamber that was, in turn, connected to a variable speed infusion pump. A small diameter fused silica tubing extended internally through the probe with one end resting $0.5 \mathrm{~mm}$ from the tip of the probe and the other end exiting the PE tubing $35 \mathrm{~cm}$ below the infusion swivel. The probe was secured in place by stainlesssteel collars that were screwed onto the guide cannula. The external length of the PE tubing was protected from chewing by a steel spring casing.

\section{Drugs and Dosages}

Heroin (diacetylmorphine $\mathrm{HCl}$ ) was obtained from Health and Welfare Canada and dissolved in physiological saline. Four different doses were used: $0.0,3.5,7.0$, and $14.0 \mathrm{mg} / \mathrm{kg} /$ day. The middle dose $(7.0 \mathrm{mg} / \mathrm{kg} /$ day $)$ was calculated on the basis of a report by Paronis and Holtzman (1992), indicating that the $\mathrm{ED}_{50} / \mathrm{h}$ for morphine analgesia in rats is $2.8 \mathrm{mg} / \mathrm{kg} / \mathrm{h}$. Assuming a 1:10 heroin-morphine potency ratio for analgesia (Harrigan and Downs, 1978; van Ree et al, 1978), the $\mathrm{ED}_{50} / \mathrm{h}$ for heroin was calculated to be about $0.3 \mathrm{mg} / \mathrm{kg} / \mathrm{h}$ (rounded to $7.0 \mathrm{mg} / \mathrm{kg} /$ day). The doses of heroin were delivered for a total of 14 days, which was the duration of delivery specific to the Alzet pumps used. Animals receiving the highest dose (ie $14.0 \mathrm{mg} / \mathrm{kg} / \mathrm{day}$ ) were injected (s.c.) with $1 \mathrm{mg} / \mathrm{kg}$ of naloxone $\mathrm{HCl}$ (DuPont NEN, Wilmington, DE) just before the implantation of the minipumps. This was performed to prevent death by overdose during the first few hours after the implant.

Cocaine $\mathrm{HCl}$ was obtained from $\mathrm{DBH}$ Chemicals (Toronto, ON), dissolved in physiological saline, and injected (i.p.) at 5 and $20 \mathrm{mg} / \mathrm{kg}$. The lowest dose was selected on the basis of studies indicating that $5 \mathrm{mg} / \mathrm{kg}$ is the minimum dose required to induce a significant conditioned place preference (Bardo et al, 1995). The higher dose was selected on the basis of previous studies showing that it reliably reinstates operant responding in animals trained to self-administer cocaine (Erb et al, 1998; Worley et al, 1994).

\section{PROCEDURES}

\section{Locomotor Activity}

Table 1 summarizes critical information about experimental groups (sizes, heroin doses, and vehicle/cocaine injections) used in each test of locomotion. The table also indicates in which figure the behavioral results for each group/test are presented.

Locomotor activity was assessed five times, and each time the behavior was monitored for $2 \mathrm{~h}$. The first test (Baseline) marked the beginning of the experiment. Following this test, the rats were assigned to four groups ( $n=27$ per group) matched on the basis of baseline activity. Groups received mini-pumps releasing $0.0,3.5,7.0$, or $14.0 \mathrm{mg} / \mathrm{kg} /$ day of heroin immediately after the baseline test.

The second test (Vehicle Test) occurred 6 days after implantation of the mini-pumps. Animals were brought to the activity chambers, and all of them $(n=27$ in each group) were injected with vehicle (ie physiological saline). The third test (Cocaine Test I) took place 13 days after implantation of the mini-pumps. For this test, nine rats from each group received a vehicle injection, nine others received an injection of $5 \mathrm{mg} / \mathrm{kg}$ of cocaine, and nine others received $20 \mathrm{mg} / \mathrm{kg}$ of cocaine, 5 min before being placed in the activity chambers.

The day after Cocaine Test I, the mini-pumps were removed. After $24 \mathrm{~h}$, all animals were tested for the fourth time (Cocaine Test II) under conditions of acute, spontaneous withdrawal from heroin. In this test, the same subgroups as in Cocaine Test I received injections of vehicle, 5 or $20 \mathrm{mg} / \mathrm{kg}$ of cocaine. 
Table I Summary of Procedural Information for the Four Tests of Locomotor Activity

\begin{tabular}{|c|c|c|c|c|c|c|c|c|c|c|c|c|c|c|}
\hline \multirow[b]{2}{*}{$\begin{array}{c}\text { Heroin } \\
\text { (mg/kg/day) }\end{array}$} & \multicolumn{2}{|c|}{ Baseline test } & \multicolumn{3}{|c|}{ Vehicle test } & \multicolumn{3}{|c|}{ Cocaine test I } & \multicolumn{3}{|c|}{ Cocaine test II } & \multicolumn{3}{|c|}{ Cocaine test III } \\
\hline & $\begin{array}{c}\text { Injection } \\
\& \\
n\end{array}$ & Figure & $\begin{array}{l}\text { Mini- } \\
\text { pump }\end{array}$ & $\begin{array}{c}\text { Injection } \\
\& \\
n\end{array}$ & Figure & $\begin{array}{l}\text { Mini- } \\
\text { pump }\end{array}$ & $\begin{array}{c}\text { Injection } \\
\& \\
n\end{array}$ & Figure & $\begin{array}{l}\text { Mini- } \\
\text { pump }\end{array}$ & $\begin{array}{c}\text { Injection } \\
\& \\
n\end{array}$ & Figure & $\begin{array}{l}\text { Mini- } \\
\text { pump }\end{array}$ & $\begin{array}{c}\text { Injection } \\
\& \\
n\end{array}$ & Figure \\
\hline \multirow[t]{6}{*}{0.0} & N/A & I & 6 days & Vehicle & $1 / 2 \mathrm{a}$ & 13 days & Vehicle & I & $\begin{array}{l}24 \mathrm{~h} \text { after } \\
\text { removal }\end{array}$ & Vehicle & । & $\begin{array}{l}14 \text { days after } \\
\text { removal }\end{array}$ & Vehicle & I \\
\hline & 27 & & & 27 & $2 \mathrm{a}$ & & 9 & $4 a$ & & 9 & $2 / 4 b$ & & 9 & $4 c$ \\
\hline & & & & & & & $5 \mathrm{mg} / \mathrm{kg}$ cocaine & $4 a$ & & $5 \mathrm{mg} / \mathrm{kg}$ cocaine & $4 b$ & & $5 \mathrm{mg} / \mathrm{kg}$ cocaine & $4 c$ \\
\hline & & & & & & & 9 & & & 9 & & & 9 & \\
\hline & & & & & & & $20 \mathrm{mg} / \mathrm{kg}$ cocaine & $4 a$ & & $20 \mathrm{mg} / \mathrm{kg}$ cocaine & $4 b$ & & $20 \mathrm{mg} / \mathrm{kg}$ cocaine & $4 c$ \\
\hline & & & & & & & 9 & & & 9 & & & 9 & \\
\hline \multirow[t]{6}{*}{3.5} & N/A & & 6 days & Vehicle & & 13 days & Vehicle & I & $\begin{array}{l}24 \mathrm{~h} \text { after } \\
\text { removal }\end{array}$ & Vehicle & । & $\begin{array}{l}14 \text { days after } \\
\text { removal }\end{array}$ & Vehicle & I \\
\hline & 27 & & & 27 & $2 \mathrm{a}$ & & 9 & $4 a$ & & 9 & $2 / 4 b$ & & 9 & $4 c$ \\
\hline & & & & & & & $5 \mathrm{mg} / \mathrm{kg}$ cocaine & $4 a$ & & $5 \mathrm{mg} / \mathrm{kg}$ cocaine & $4 b$ & & $5 \mathrm{mg} / \mathrm{kg}$ cocaine & $4 c$ \\
\hline & & & & & & & 9 & & & 9 & & & 9 & \\
\hline & & & & & & & $20 \mathrm{mg} / \mathrm{kg}$ cocaine & $4 a$ & & $20 \mathrm{mg} / \mathrm{kg}$ cocaine & $4 b$ & & $20 \mathrm{mg} / \mathrm{kg}$ cocaine & $4 c$ \\
\hline & & & & & & & 9 & & & 9 & & & 9 & \\
\hline \multirow[t]{6}{*}{7.0} & N/A & & 6 days & Vehicle & & 13 days & Vehicle & I & $\begin{array}{l}24 \mathrm{~h} \text { after } \\
\text { removal }\end{array}$ & Vehicle & I & $\begin{array}{l}14 \text { days after } \\
\text { removal }\end{array}$ & Vehicle & I \\
\hline & 27 & & & 27 & $2 \mathrm{a}$ & & 9 & $4 a$ & & 9 & $2 / 4 b$ & & 9 & $4 c$ \\
\hline & & & & & & & $5 \mathrm{mg} / \mathrm{kg}$ cocaine & $4 a$ & & $5 \mathrm{mg} / \mathrm{kg}$ cocaine & $4 b$ & & $5 \mathrm{mg} / \mathrm{kg}$ cocaine & $4 c$ \\
\hline & & & & & & & 9 & & & 9 & & & 9 & \\
\hline & & & & & & & $20 \mathrm{mg} / \mathrm{kg}$ cocaine & $4 a$ & & $20 \mathrm{mg} / \mathrm{kg}$ cocaine & $4 b$ & & $20 \mathrm{mg} / \mathrm{kg}$ cocaine & $4 c$ \\
\hline & & & & & & & 9 & & & 9 & & & 9 & \\
\hline \multirow[t]{6}{*}{14.0} & N/A & & 6 days & Vehicle & & 13 days & Vehicle & I & $\begin{array}{l}24 \mathrm{~h} \text { after } \\
\text { removal }\end{array}$ & Vehicle & । & $\begin{array}{l}14 \text { days after } \\
\text { removal }\end{array}$ & Vehicle & I \\
\hline & 27 & & & 27 & $2 \mathrm{a}$ & & 9 & $4 a$ & & 9 & $2 / 4 b$ & & 9 & $4 c$ \\
\hline & & & & & & & $5 \mathrm{mg} / \mathrm{kg}$ cocaine & $4 a$ & & $5 \mathrm{mg} / \mathrm{kg}$ cocaine & $4 b$ & & $5 \mathrm{mg} / \mathrm{kg}$ cocaine & $4 c$ \\
\hline & & & & & & & 9 & & & 9 & & & 9 & \\
\hline & & & & & & & $20 \mathrm{mg} / \mathrm{kg}$ cocaine & $4 a$ & & $20 \mathrm{mg} / \mathrm{kg}$ cocaine & $4 b$ & & $20 \mathrm{mg} / \mathrm{kg}$ cocaine & $4 c$ \\
\hline & & & & & & & 9 & & & 9 & & & 9 & \\
\hline
\end{tabular}


Finally, 14 days after the removal of the pumps, all animals were tested for the fifth and last time (Cocaine Test III) under conditions of prolonged withdrawal from heroin. Once again, the same subgroups received injections of vehicle, 5 or $20 \mathrm{mg} / \mathrm{kg}$ of cocaine.

\section{Self-Administration}

The timing of the self-administration studies was determined by the priority given to locomotor studies. Thus, a week after the last locomotor activity test (ie Cocaine Test III), all animals that had never been given cocaine in the locomotion tests, but that had been exposed to heroin $(0.0$, $3.5,7.0$, or $14.0 \mathrm{mg} / \mathrm{kg} / \mathrm{day}, n=9$ per group), received intravenous surgery. After 1 week, they were tested for cocaine self-administration under three different conditions. These three conditions were chosen on the basis of previous reports indicating that rats with enhanced sensitivity to the behavioral activating effects of stimulants will self-administer more stimulants at low doses, show enhanced escalation of drug intake, and display an upward shift in dose-response for cocaine self-administration (Deroche et al, 1999; Piazza et al, 2000; Mantsch et al, 2001). Thus, in the first condition, the propensity to selfadminister a low dose of cocaine, $0.13 \mathrm{mg} / \mathrm{kg} /$ infusion, was assessed over 3 consecutive days in 6-h sessions. In the second, the escalation of drug intake was studied over 10 consecutive days in 3-h sessions; for this test the dose of cocaine was increased to $0.5 \mathrm{mg} / \mathrm{kg} /$ infusion. Finally, the dose-response for cocaine self-administration was assessed by giving each group two daily 3 -h sessions with a given dose, beginning with $0.13 \mathrm{mg} / \mathrm{kg} /$ infusion and then moving to $0.25,0.5$, and to $1 \mathrm{mg} / \mathrm{kg} /$ infusion.

For each self-administration session, the rats were moved from their home cages to the operant chambers and their connectors were attached to the infusion lines. Each session started with the activation of the red house light, the entry of the retractable lever, and the illumination of the light CS for $30 \mathrm{~s}$. If the animal pressed the active lever during this first 30-s presentation of the light CS, it received an infusion followed by termination of the light after $10 \mathrm{~s}$. Subsequently, presses led to infusions of cocaine on a fixed-ratio 1 (FR1) schedule of reinforcement. The drug was infused at a volume of $64 \mu \mathrm{l}$ over a 10-s period. During this period, the light CS was illuminated serving as a CS paired with the drug infusion. Responses on the active lever made during the infusion were recorded, but did not lead to further infusions. The drug concentration was adjusted for differences in body weight.

\section{Microdialysis}

The microdialysis study was conducted in a separate group of rats. These rats were randomly assigned to four groups ( $n=8$ per group) and were implanted with osmotic minipumps releasing $0.0,3.5,7.0$, and $14.0 \mathrm{mg} / \mathrm{kg} /$ day of heroin. At 12 days after the implant, the animals were brought to the testing chambers and the microdialysis probes were inserted. To prevent blockage, artificial cerebrospinal fluid (ACSF; $145 \mathrm{mM} \mathrm{Na}^{+}, 2.7 \mathrm{mM} \mathrm{K}^{+}, 1.22 \mathrm{mM} \mathrm{Ca}^{2+}, 1.0 \mathrm{mM}$ $\mathrm{Mg}^{2+}, 150 \mathrm{mM} \mathrm{Cl}-, 0.2 \mathrm{mM}$ ascorbate, $2 \mathrm{mM} \mathrm{Na}_{2} \mathrm{HPO}_{4}$, $\mathrm{pH}=7.4)$ was perfused overnight at a rate of $0.25 \mu \mathrm{l} / \mathrm{min}$.
The following morning, the dialysate flow rate was increased to $0.6 \mu \mathrm{l} / \mathrm{min}$ and samples were collected every $20 \mathrm{~min}$ for $2 \mathrm{~h}$ (Pump IN phase). The mini-pumps were then removed. After $24 \mathrm{~h}$, dialysis was resumed during the period of acute, spontaneous withdrawal from heroin (Pump OUT phase), and then, $1 \mathrm{~h}$ later following an injection of $20 \mathrm{mg} / \mathrm{kg}$ of cocaine.

During sampling, a $10 \mu \mathrm{l}$ volume of dialysate was used from each sample and immediately analyzed for DA and its metabolites, DOPAC and HVA using high-performance liquid chromatography with electrochemical detection (HPLC-EC). The samples were loaded onto a reverse phase column $\left(15 \times 4.6 \mathrm{~mm}^{2}\right.$ Hasil C18, $5 \mu \mathrm{m}$; S.P.E. Limited $)$ through a manual injection port (Reodyn $7125 ; 20 \mu$ loop). The oxidation and reduction currents for DA, DOPAC, and HVA were measured with a dual channel ESA coulometric detector model 5100 with a model 5011 analytical cell. The mobile phase ( $15 \%$ Acetonitrile $0.076 \mathrm{M}$ SDS, 0.1 M EDTA, $0.058 \mathrm{M} \mathrm{NaPO}_{4}, 0.27 \mathrm{M}$ citric acid, $\mathrm{pH}=3.35$ ) was circulated through the system at a flow rate of $1.3 \mathrm{ml} / \mathrm{min}$ by a waters 515 HPLC pump. The peaks obtained were integrated and quantified by the EZChrom chromatography data system (S.P.E. Limited, Concord, ON, Canada)

\section{Statistical Analyses}

All data were analyzed using analysis of variance (ANOVA), with either of the factors (ie one-way ANOVA betweensubjects design), two independent factors, or two factors with one repeated measure (ie two-way ANOVA mixed design). Subsequent tests for differences between group means were carried out using the Fisher LSD test for multiple comparisons $(p<0.05)$.

\section{RESULTS}

\section{Locomotion and Body Weight}

Effect of heroin treatment alone on locomotor activity. Figure 1 shows the mean locomotor activity displayed by rats in the four groups $(0.0,3.5,7.0$, and $14.0 \mathrm{mg} / \mathrm{kg} / \mathrm{day}$ of heroin) that received vehicle injections on all five tests. The lack of differences at baseline (panel 1) shows that the groups were successfully equated for initial locomotion. It can be seen, however, that on the test given 6 days after mini-pump implantation (panel 2), chronic heroin exposure dose dependently elevated locomotor activity $(\mathrm{F}(3,104)=36.19, p<0.0001)$. A similar group effect was observed when rats were tested 13 days after the implantation of the mini-pumps $(\mathrm{F}(3,32)=13.83, p<0.0001)$ (panel 3 ). Visual inspection of panels 2 and 3 of Figure 1 suggests that the locomotor effects of chronic heroin exposure increased from day 6 to day 13 following implantation of the pumps. It should be noted, however, that all animals $(n=27$ per group) were injected with vehicle after 6 days of heroin exposure, whereas only nine subjects were injected with vehicle after 13 days of heroin exposure and, therefore, the data from these 2 test days cannot be compared directly. However, an ANOVA was performed on the data from only those rats that received vehicle on both tests, but no significant effect of the test was found. This suggests that elevation of spontaneous locomotion induced by heroin did 


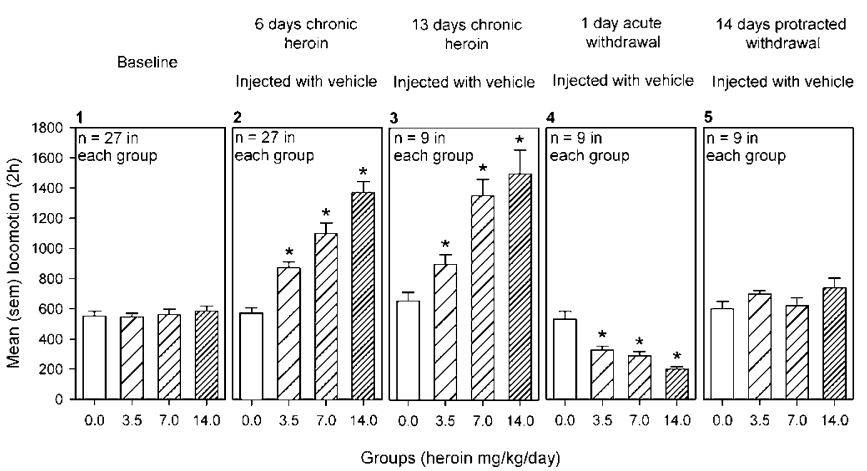

Figure I Mean (SEM) locomotor activity in rats implanted with minipumps releasing $0.0,3.5,7.0$, or $14.0 \mathrm{mg} / \mathrm{kg} / \mathrm{day}$ of heroin that received vehicle injections in all five tests sessions. The Baseline test was performed before the implant of the mini-pumps. *Indicates a significant difference $(\alpha<0.05)$ from the $0.0 \mathrm{mg} / \mathrm{kg} /$ day group.

not increase significantly after a second week of chronic exposure. When rats were tested during acute, spontaneous withdrawal from heroin (panel 4), locomotor activity was found to be depressed in a dose-dependent manner $(\mathrm{F}(3,32)=19.47, p<0.0001)$. Finally, no significant group differences were observed in the vehicle-injected rats when tested 14 days following the removal of the pumps (panel 5).

Figure 2 shows the time course of the change in locomotor activity in the tests given during chronic heroin exposure and during acute withdrawal, in rats injected with vehicle. Figure 2 (panel a) shows the activity of the groups ( $n=27$ each) during the test given after 6 days of chronic heroin treatment. The ANOVA revealed the presence of a significant Group by Session Time interaction $(\mathrm{F}(21,728)=6.25, p<0.0001)$; multiple comparisons identified three important differences. First, at the beginning of the session, rats in the $14.0 \mathrm{mg} / \mathrm{kg} /$ day group were significantly more active than those in all the other groups. Second, activity decreased over the course of the session in all groups. Third, during the last $15 \mathrm{~min}$ of the session, all groups with heroin pumps were more active than the group with vehicle pumps.

Figure 2 (panel b) shows the activity of the groups injected with vehicle during acute withdrawal from heroin. The ANOVA revealed significant main effects of Group $(\mathrm{F}(3,32)=19.47, \quad p<0.0001) \quad$ and of Session Time $(\mathrm{F}(7,224)=59.61, p<0.0001)$. Multiple comparisons revealed no group differences during the first $15 \mathrm{~min}$ of testing, whereas after the first hour, rats in withdrawal from heroin had significantly lower activity scores than vehicletreated rats. This effect was evident until the end of the session.

Chronic heroin exposure significantly reduced the gain in body weight that occurred in the 2 weeks between the implantation and removal of the mini-pumps (mean \% change in weight: $0.0 \mathrm{mg} / \mathrm{kg} /$ day $=16.7 \pm 0.7 ; 3.5 \mathrm{mg} / \mathrm{kg} /$ day $=17.3 \pm 1.0 ; \quad 7.0 \mathrm{mg} / \mathrm{kg} /$ day $=13.9 \pm 0.8 ; \quad 14.0 \mathrm{mg} / \mathrm{kg} /$ day $=14.7 \pm 1.0 ;(\mathrm{F}(3,104)=3.33, p<0.05))$. Acute, spontaneous withdrawal from heroin was accompanied by a further decrease in body weight. Figure 3 shows the percent change in weight in the $24 \mathrm{~h}$ following removal of the pumps (panel a), and from the time of implantation of the pump to the end of the locomotion experiment, 28 days later

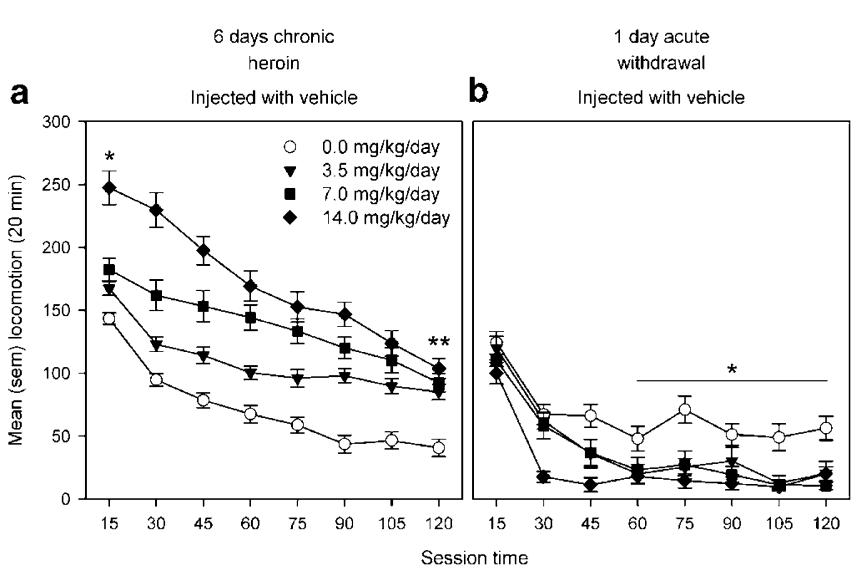

Figure 2 (a) Mean (SEM) locomotor activity, in 15-min intervals, after 6 days of chronic heroin exposure, in rats that received vehicle injections. *Indicates a significant difference $(\alpha<0.05)$ between the $14.0 \mathrm{mg} / \mathrm{kg} / \mathrm{day}$ heroin group and all other groups. **Indicates a significant difference $(\alpha<0.05)$ between all heroin-treated groups and the vehicle-treated group. (b) Mean (SEM) locomotor activity, in 15-min intervals, $24 \mathrm{~h}$ after the removal of the mini-pumps, in rats that received vehicle injections. *Indicates a significant difference $(\alpha<0.05)$ between all heroin-treated groups and the vehicle-treated group.

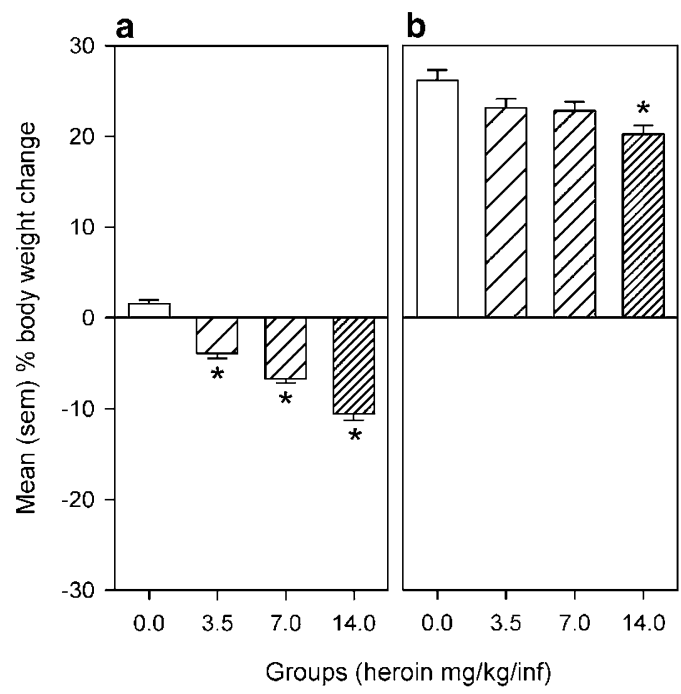

Figure 3 (a) Mean (SEM) \% change in body weight in the $24 \mathrm{~h}$ following removal of the heroin-filled mini-pumps. *Indicates a significant difference $(\alpha<0.05)$ from the $0.0 \mathrm{mg} / \mathrm{kg} /$ day group. (b) Mean (SEM) \% change in body weight from the time of implantation of the pump to the end of the experiment, 28 days later. *Indicates a significant difference $(\alpha<0.05)$ from the $0.0 \mathrm{mg} / \mathrm{kg} /$ day group.

(panel b). As can be seen, acute, spontaneous withdrawal from heroin caused a significant, and dose-dependent loss in body weight $(\mathrm{F}(3,104)=89.56, p<0.0001)$, which did not fully recover by the end of the experiment $(\mathrm{F}(3,104)=5.67$, $p<0.05)$.

Effects of cocaine on locomotor activity in heroin-treated animals. Figure 4 shows the effects of vehicle and cocaine injections on locomotor activity, measured over $2 \mathrm{~h}$, in rats tested during chronic exposure to heroin (panel a), during 
acute, spontaneous withdrawal (panel b), and during prolonged withdrawal from heroin (panel c). The smaller graphs (panels a1, b1, and $\mathrm{c} 1$ ) represent the percent change in locomotion activity caused by cocaine injections, in the vehicle- (no heroin) and heroin-treated (all heroin) rats, on each of the tests. As can be seen in Figure 4 (panel a), cocaine dose dependently elevated locomotion in all groups chronically maintained on heroin. The ANOVA revealed significant main effects of Group $(\mathrm{F}(3,6)=24.26, p<0.0001)$ and Drug injection $(\mathrm{F}(2,6)=21.07, p<0.0001)$, and multiple comparisons indicated that only $20 \mathrm{mg} / \mathrm{kg}$ elevated locomotion significantly in all groups. The lack of a significant interaction suggests that the increase in locomotor activity induced by cocaine was additive to the already existing elevation induced by chronic exposure to heroin. This information is best displayed in panel a1 of Figure 4, where it is apparent that the effects of cocaine were similar in vehicle- and heroin-treated animals.

Figure 4 (panel b) shows that cocaine dose dependently reversed the depression of locomotor activity caused by acute, spontaneous withdrawal from heroin. Thus, there was a significant effect of Group $(\mathrm{F}(3,6)=7.28, p<0.0001)$ and Drug injection $(\mathrm{F}(2,6)=109.76, p<0.0001)$. Multiple comparisons confirmed that cocaine at $20 \mathrm{mg} / \mathrm{kg}$ elevated locomotion over levels seen after vehicle injections in all groups, while for the $5 \mathrm{mg} / \mathrm{kg}$ dose, this effect was significant only for the 3.5 and $7.0 \mathrm{mg} / \mathrm{kg} /$ day heroin groups. The normalized data represented in panel b1 of Figure 4, indicate that the stimulatory effects of cocaine were significantly larger in animals experiencing acute heroin withdrawal (main effect of heroin $(\mathrm{F}(1,1)=16.12$, $p<0.001)$; main effect of cocaine $(\mathrm{F}(1,1)=21.58$, $p<0.0001)$ ), probably because the activity of vehicleinjected rats used to normalize the data was lowered by withdrawal.

Figure 4 (panel c) shows the effects of cocaine injections given during protracted withdrawal from heroin. The ANOVA indicated a significant main effect of Drug injection $(\mathrm{F}(2,6)=87.36, \quad p<0.0001)$ and multiple comparisons showed that $20 \mathrm{mg} / \mathrm{kg}$ cocaine significantly elevated activity over vehicle levels in all groups. In contrast, $5 \mathrm{mg} / \mathrm{kg}$ cocaine induced a significant increase in activity in vehicleinjected rats only in the 7.0 and in the $14.0 \mathrm{mg} / \mathrm{kg} /$ day groups, suggesting a sensitized locomotor response to the lower cocaine dose in these rats previously exposed to heroin. Furthermore, the level of activity induced by $5 \mathrm{mg} /$ $\mathrm{kg}$ of cocaine in the $14.0 \mathrm{mg} / \mathrm{kg} /$ group was significantly different from that induced in the $0.0 \mathrm{mg} / \mathrm{kg} / \mathrm{group}$. This sensitized response to the lower cocaine dose in herointreated animals is also evident in the normalized data shown in panel c1 (main effect of cocaine: $(\mathrm{F}(1,1)=47.07$, $p<0001))$.

\section{Self-Administration of Cocaine}

Responses made on the inactive lever by the groups did not differ during any of the self-administration phases described below. In addition, although these experiments employed an FR1 schedule, responses outnumbered infusions because of nonreinforced responding that occurred during the drug infusions. This is a typical phenomenon observed in our cocaine self-administration experiments,
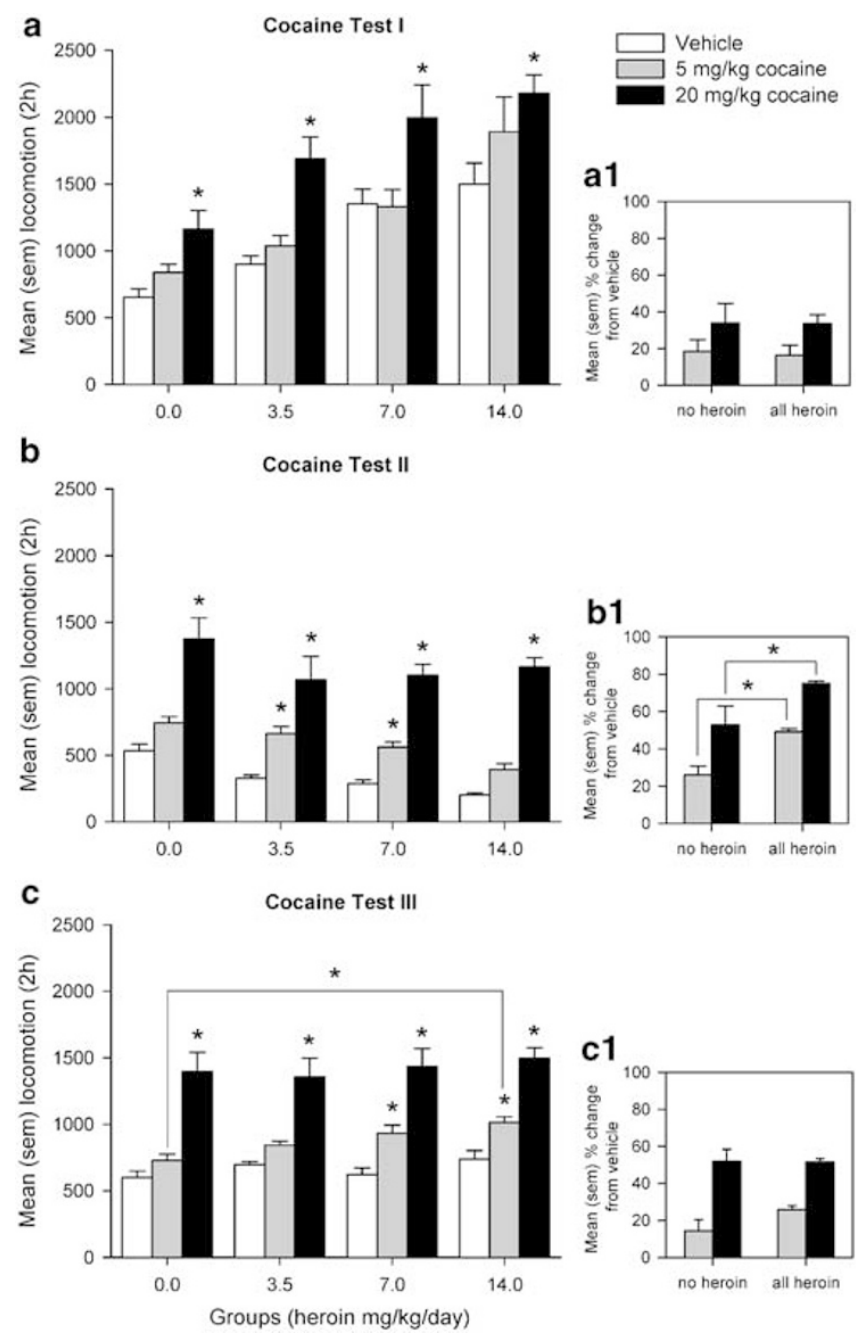

Figure 4 Mean (SEM) locomotor activity induced by acute injections of cocaine (vehicle, 5 and $20 \mathrm{mg} / \mathrm{kg}$ ) administered to rats chronically exposed to $0.0,3.5,7.0$, and $14.0 \mathrm{mg} / \mathrm{kg} /$ day of heroin (a), to the same rats tested during acute, spontaneous heroin withdrawal (b), and again to the same rats tested 14 days following the removal of the mini-pumps (c). Panels (al, $\mathrm{bl}$, and $\mathrm{Cl}$ ) represent mean (SEM) \% change in activity from vehicle injection induced by cocaine in vehicle-treated animals (no heroin) and in heroin-treated rats (all heroin). The average activity in three heroin-dose groups was used to calculate \% changes. Unless otherwise indicated in the figures, *represents a significant difference $(\alpha<0.05)$ from rats injected with vehicle.

and it has been reported in more detail elsewhere (Leri and Stewart, 2001).

Intake of a low dose of cocaine ( $0.13 \mathrm{mg} / \mathrm{kg} / \mathrm{infusion})$. Figure 5 shows the self-administration of a low dose of cocaine $(0.13 \mathrm{mg} / \mathrm{kg} /$ infusion $)$ in rats previously exposed to heroin $(0.0,3.5,7.0$, and $14.0 \mathrm{mg} / \mathrm{kg} /$ day $)$, but never to cocaine challenges. The bar graphs (panels a1, a2, and a3) show the mean infusions on each of the 6-h selfadministration sessions. Statistical analyses revealed significant group effects during each session (Session 1: $\mathrm{F}(3,25)=3.48, p<0.05$; Session 2: $\mathrm{F}(3,25)=3.83, p<0.05$; Session 3: $\mathrm{F}(3,25)=3.76, p<0.05)$. Rats previously exposed to the two higher doses of heroin self-administered more cocaine than those exposed to vehicle during each session. 

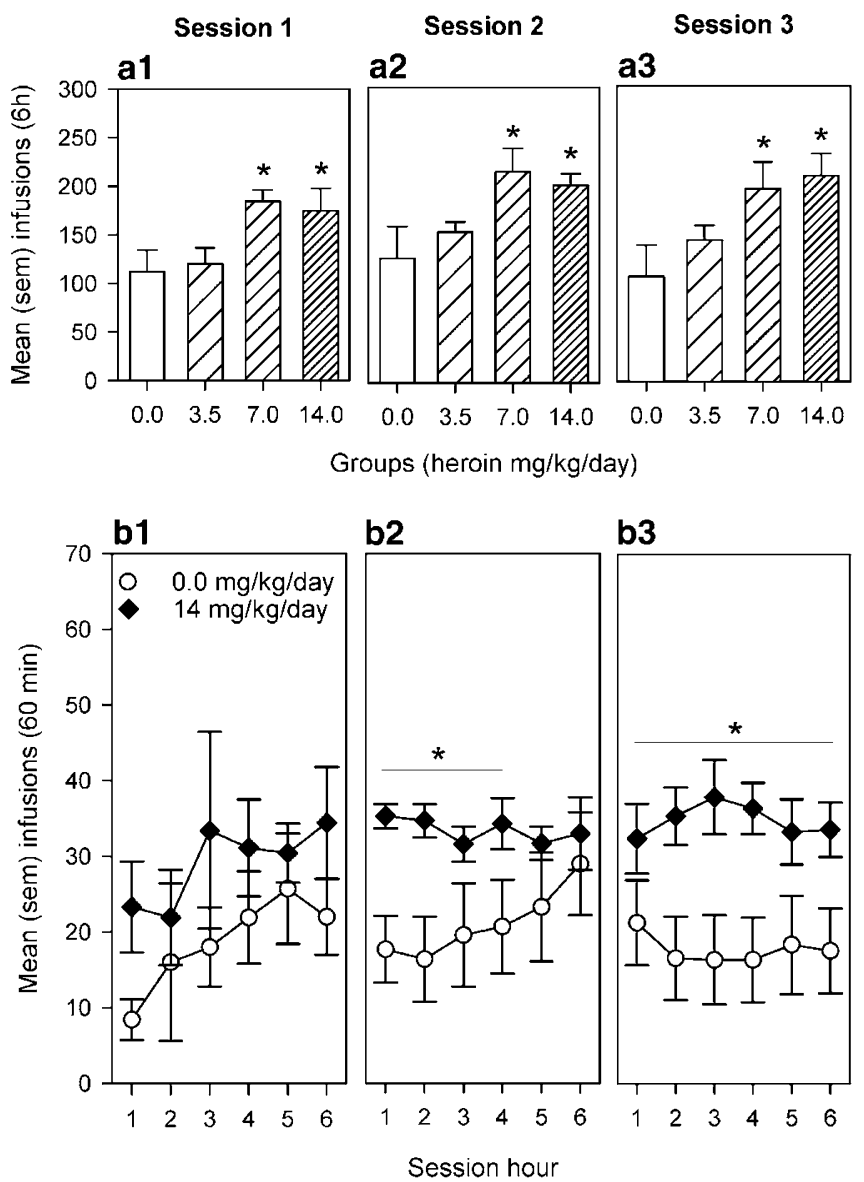

Figure 5 (al-a3) Mean (SEM) infusions of a low cocaine dose $(0.13 \mathrm{mg} /$ $\mathrm{kg} /$ infusion) self-administered by rats previously exposed to heroin $(0.0,3.5$, 7.0 , or $14.0 \mathrm{mg} / \mathrm{kg} /$ day), during three separate 6 -h sessions. * Indicates a significant difference $(\alpha<0.05)$ from the $0.0 \mathrm{mg} / \mathrm{kg} /$ day group. Panels $(b \mathrm{l}-$ b3) compare mean (SEM) number of infusions/hour self-administered by rats previously exposed to 0.0 and to $14.0 \mathrm{mg} / \mathrm{kg} /$ day of heroin, over the three, 6-h sessions.

Figure 5 (panels b1, b2, and b3) compares the number of infusions $/ \mathrm{h}$ in the vehicle- and in the $14.0 \mathrm{mg} / \mathrm{kg} / \mathrm{day}$ heroin-treated groups. In all three sessions, the $14.0 \mathrm{mg} /$ $\mathrm{kg} /$ day group took a greater number of infusions of cocaine, but the difference was statistically significant only in Sessions 2 and 3 (Session 2: main effect of Group, $\mathrm{F}(1,12)=4.68, p<0.05$; Session 3: main effect of Group, $\mathrm{F}(1,12)=6.88, p<0.05)$.

Escalation of intake of cocaine. Following acquisition of self-administration of the low dose of cocaine, the escalation of intake of a higher dose of cocaine $(0.5 \mathrm{mg} / \mathrm{kg} /$ infusion $)$ was studied over ten 3 -h sessions. Panel al of Figure 6 shows the mean number of infusions taken over the 10 days, while panel a2 shows the difference between the number of infusions obtained on the first and the last self-administration session for each group. Although rats previously exposed to heroin appeared to show a larger increase in cocaine intake over days, the group differences were not statistically significant. Figure 6 (panel b) compares the number of infusions of cocaine obtained by the 0.0 and the
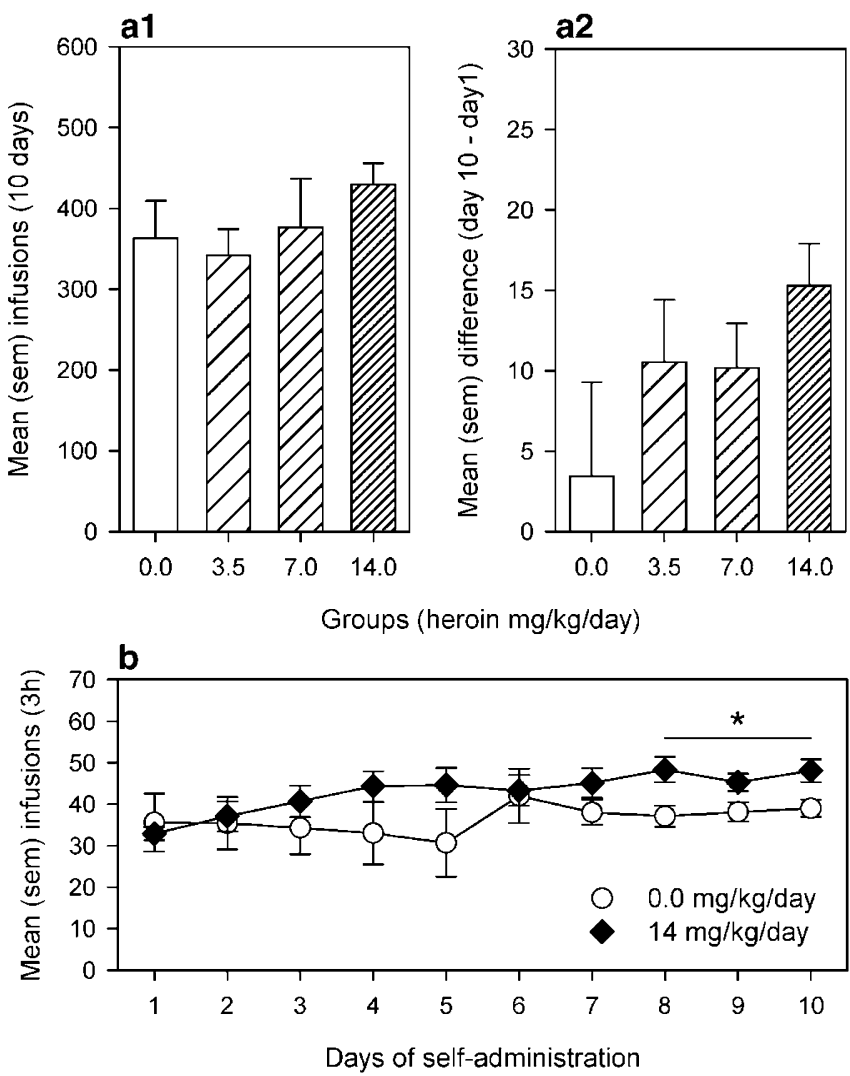

Figure 6 (al) Mean (SEM) infusions of $0.5 \mathrm{mg} / \mathrm{kg} /$ infusion of cocaine selfadministered by the groups over 10, 3-h sessions. (a2) Mean (SEM) differences between the number of infusions obtained on the first and the last self-administration session for each group. (b) Mean (SEM) number of infusions, for each of the 10 3-h sessions, self-administered by rats previously exposed to 0.0 and to $14.0 \mathrm{mg} / \mathrm{kg} /$ day of heroin.

$14.0 \mathrm{mg} / \mathrm{kg} /$ day heroin groups over the 10 days of selfadministration. The ANOVA revealed a significant effect of Session $(F(9,108)=2.52, p<0.05)$, suggesting that intake changed over sessions. Multiple comparisons revealed that rats exposed to the highest dose of heroin self-administered more cocaine than the rats exposed to vehicle over the last 3 days of self-administration.

Dose-response of cocaine self-administration. Figure 7 shows the mean number of infusions and responses for different doses of cocaine during the 3-h self-administration sessions. Two tests were given with each dose, and all groups were presented with the lowest dose $(0.13 \mathrm{mg} / \mathrm{kg} /$ infusion) first and the highest dose ( $1 \mathrm{mg} / \mathrm{kg} /$ infusion) last. The statistical analysis was carried out on the data from the second test with each dose. For both infusions and responses, the ANOVA revealed significant main effects of Group and Dose (Infusions: Group: $\mathrm{F}(3,25)=3.24, p<0.05$, Dose: $\quad \mathrm{F}(3,75)=48.72, \quad p<0.0001$; Responses: Group: $\mathrm{F}(3,25)=4.22, p<0.05$, Dose: $\mathrm{F}(3,75)=40.22, p<0.0001)$. It can be seen that, except at the highest dose of cocaine, the group previously exposed to $14.0 \mathrm{mg} / \mathrm{kg} /$ day of heroin consistently self-administered more cocaine. Multiple comparisons revealed that this effect was statistically significant only at the lowest dose of cocaine. 


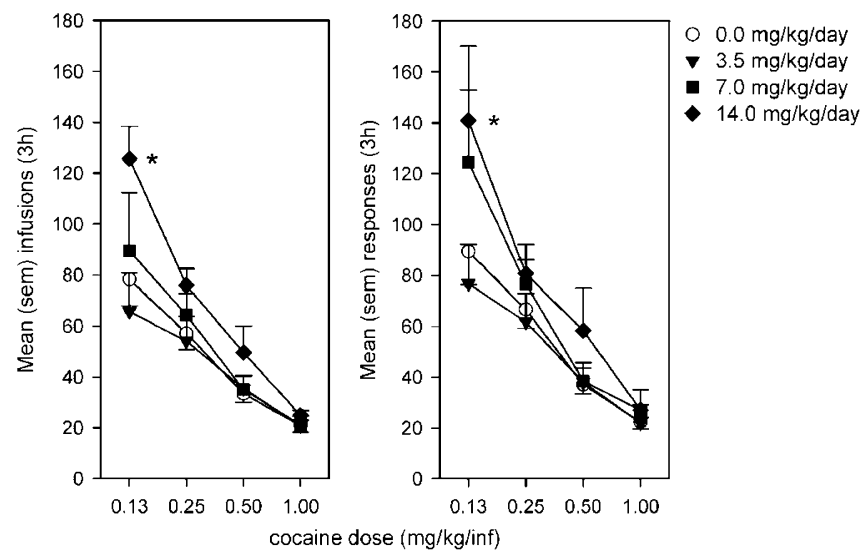

Figure 7 Mean (SEM) number of infusions and responses for different doses of cocaine $(0.13,0.25,0.50$, and $1.00 \mathrm{mg} / \mathrm{kg} /$ infusion) selfadministered by the experimental groups during a 3-h session. *Indicates a significant difference $(\alpha<0.05)$ between the 0.0 and the $14.0 \mathrm{mg} / \mathrm{kg} /$ day heroin groups.

\section{Microdialysis}

Histological analysis revealed that in most rats the probes were located in the anterior-medial Acb, encroaching on both the shell and the core region (see Figure 8). The data from six animals were not included in the statistical analyses because the probe was misplaced. In total, six rats implanted with $0.0 \mathrm{mg} / \mathrm{kg} /$ day, seven with $3.5 \mathrm{mg} / \mathrm{kg} /$ day, six with $7.0 \mathrm{mg} / \mathrm{kg} /$ day, and seven with $14.0 \mathrm{mg} / \mathrm{kg} / \mathrm{day}$ of heroin were included in the analysis. They were tested during chronic heroin exposure (Day 13) and during acute, spontaneous withdrawal $(24 \mathrm{~h}$ after the removal of the minipumps). As can be seen from Figure 9, basal levels of DA were elevated in a dose-dependent manner in the Acb during heroin exposure. Interestingly, $24 \mathrm{~h}$ after the removal of the pumps, DA concentrations were equivalent across groups. The ANOVA revealed a significant Group by Pump interaction $(\mathrm{F}(3,22)=5.51, p<0.05)$ and multiple comparisons indicated that during chronic heroin exposure, DA was significantly elevated in the 7.0 and $14.0 \mathrm{mg} / \mathrm{kg} /$ day groups, whereas during acute withdrawal there were no group differences. The DA concentration fell significantly from the time of pump IN to pump OUT only in rats maintained on $14.0 \mathrm{mg} / \mathrm{kg} /$ day of heroin.

After sampling for basal DA levels during acute withdrawal, all rats received an injection (i.p.) of $20 \mathrm{mg} / \mathrm{kg}$ of cocaine. As can be seen in Figure 10 , cocaine significantly elevated extracellular DA in all groups, but the magnitude of the effect was reduced in rats withdrawn from heroin (Group by Sample interaction: $\mathrm{F}(24,176)=45.02$, $p<0.0001)$. Multiple comparisons confirmed that there were significant differences in DA concentration between the 0.0 and the $14.0 \mathrm{mg} / \mathrm{kg} / \mathrm{day}$ heroin-treated rats in samples $1,2,3$, and 5 .

\section{DISCUSSION}

In the present experiments, we studied the effects of chronic exposure to heroin, and withdrawal from heroin, on the responses of rats to cocaine with the goal of identifying possible reasons for cocaine use by opioid addicts. It was

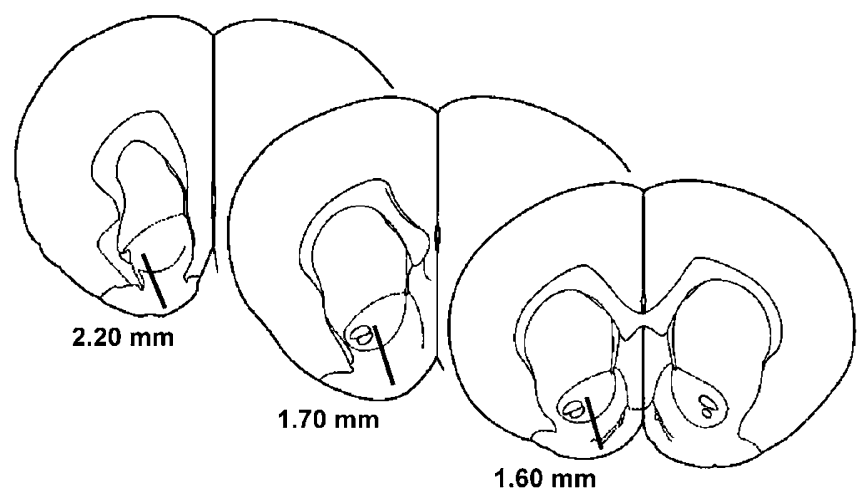

Figure 8 Verified location of the microdialysis probes implanted in the Acb, plotted on drawings of coronal sections from the atlas of Paxinos and Watson (1997).

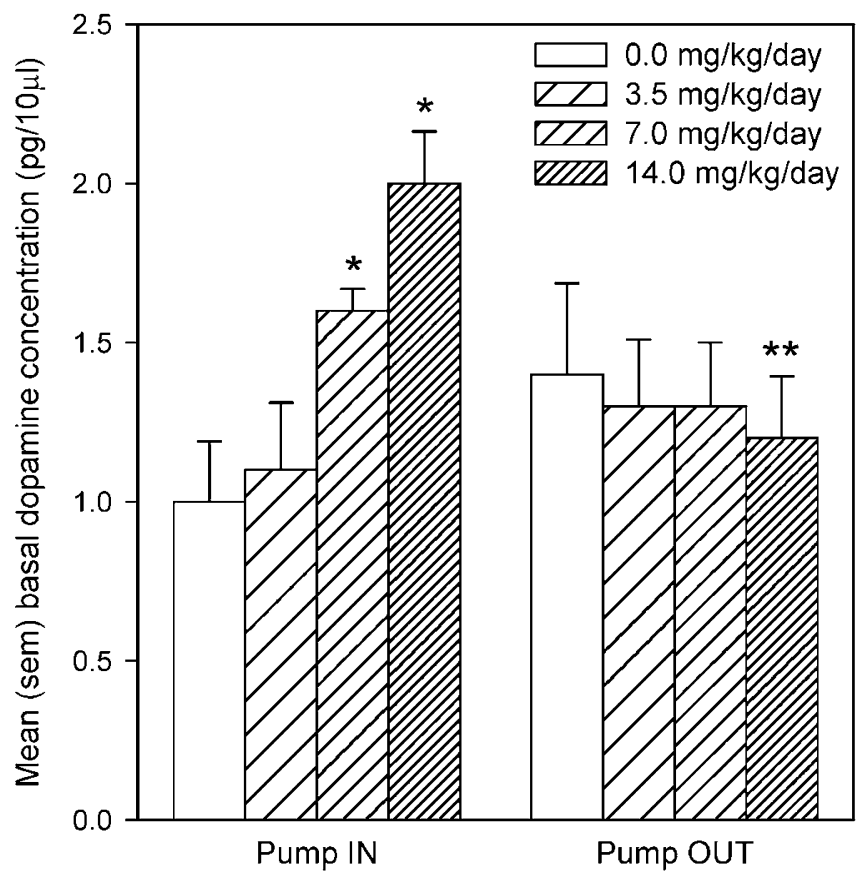

Figure 9 Mean (SEM) basal DA concentrations sampled in the Acb of rats chronically exposed to different doses of heroin (Pump IN), and in the same rats, $24 \mathrm{~h}$ following the removal of the pumps (Pump OUT), in conditions of acute, spontaneous heroin withdrawal. *Indicates a significant difference $(\alpha<0.05)$ from the $0.0 \mathrm{mg} / \mathrm{kg} /$ day group. $* * *$ Indicates a significant difference $(\alpha<0.05)$ from Pump IN to Pump OUT.

found, first, that chronic exposure to heroin, in itself, dose dependently increased locomotor activity in tests conducted during continuous exposure, and second, that acute withdrawal from heroin caused a dose-dependent suppression of locomotion. Importantly, during continuous exposure to heroin, the stimulatory effects of an acute injection of cocaine summated with those of heroin. During acute withdrawal from heroin, cocaine reversed the behavioral depression seen at that time, and during protracted withdrawal from heroin, the stimulatory effects of cocaine were enhanced (cross-sensitization). Finally, we found that a history of heroin exposure also enhanced the subsequent voluntary self-administration of cocaine in rats never previously exposed to cocaine. 


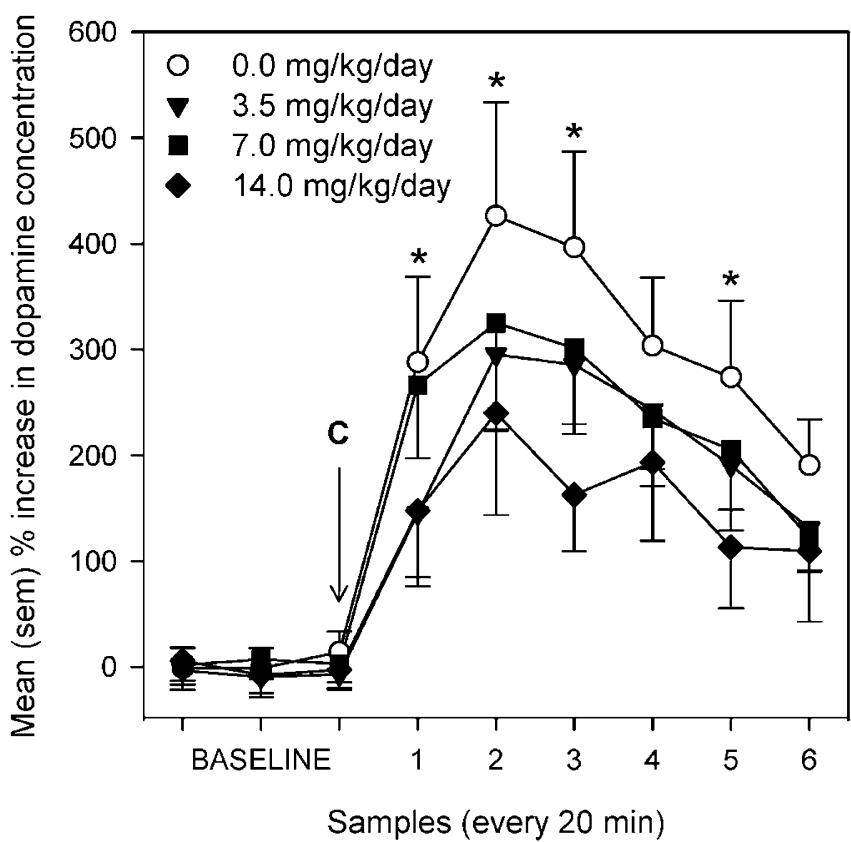

Figure 10 Mean (SEM) \% increase in DA concentration in the Acb caused by a cocaine injection $(20 \mathrm{mg} / \mathrm{kg}$, i.p. $-\mathrm{c})$ given to rats in acute, spontaneous withdrawal from different doses of heroin $(0.0,3.5,7.0$, and $14.0 \mathrm{mg} / \mathrm{kg} / \mathrm{day})$. * Indicates a significant difference $(\alpha<0.05)$ between the 0.0 and the $14.0 \mathrm{mg} / \mathrm{kg} /$ day heroin groups.

\section{Effects of Cocaine during Chronic Exposure to Heroin and During Acute Heroin Withdrawal}

In rats chronically exposed to heroin, there was an additive effect of cocaine on the enhanced locomotor activity induced by the heroin treatment. This finding is consistent with observations of synergism between opioids and cocaine in animal models of drug-reinforcement (Rowlett and Woolverton, 1997; Mello et al, 1995; Mattox et al, 1997; Wang et al, 2001; Ranaldi and Munn, 1998; Duvauchelle et al, 1998), drug-discrimination (Suzuki et al, 1997; GreenJordan et al, 2001), analgesia (Nott, 1968; Misra et al, 1987; Sierra et al, 1992; Gatch et al, 1995; Shimada et al, 1988; Kauppila et al, 1992), and drug toxicity (Plunkett et al, 1989; Blumberg and Ikeda, 1978; Leander and Lucot, 1977).

The depression in locomotor activity caused by acute, spontaneous withdrawal from heroin was reversed, dose dependently, by cocaine administration. In fact, the activity level after $20 \mathrm{mg} / \mathrm{kg}$ of cocaine in rats in withdrawal from the highest heroin dose was similar to that in the vehicletreated group injected with the same cocaine dose (see Figure 4, panel b). Others have shown, both in humans and rats physically dependent on heroin, morphine, or methadone, that a number of withdrawal signs precipitated by naloxone are attenuated by acute cocaine administration (Kosten, 1989, 1990). Thus, although we would not argue that cocaine is an appropriate treatment for opioid withdrawal sickness (Freud, 1887; Grinspoon and Bakalar, 1976), we do suggest that alleviation of withdrawal might represent another reason for cocaine use in heroin addicts.

In separate groups of rats, we examined DA activity in the nucleus accumbens during chronic heroin exposure, during acute withdrawal, and after an injection of $20 \mathrm{mg} / \mathrm{kg}$ of cocaine given during acute withdrawal. Consistent with the observation that opioid drugs can elevate DA concentrations in the Acb (Di Chiara and Imperato, 1986, 1988; Wise and Bozarth, 1987; Koob, 1992; Di Chiara, 1995; Johnson and North, 1992; Joyce and Iversen, 1979), we observed a dose-dependent elevation in the basal level of DA during chronic exposure to heroin over that seen in the vehicletreated group (see Figure 9). During acute spontaneous withdrawal from heroin, we observed a drop in basal DA levels in the three heroin-treated groups relative to their basal DA levels measured during chronic exposure. However, no differences were found in basal DA levels when the heroin-treated animals in acute withdrawal were compared to the vehicle-treated groups. Thus, our results are not consistent with previous findings indicating that spontaneous withdrawal from opioid drugs is associated with significant reductions in DA levels in the ventral striatum (Acquas et al, 1991; Acquas and Di Chiara, 1992; Crippens and Robinson, 1994; Spanagel et al, 1994). However, differently from our study, these previous reports employed daily injections of escalating doses, and this difference in temporal pattern of drug exposure could account for the contrasting neurochemical findings (Post, 1980; Kreek, 1997).

Despite the fact that basal levels of DA during acute withdrawal from heroin were not measurably different from those in vehicle-treated rats, we did find evidence for hyporesponsiveness of the mesolimbic DA system during that time (Volkow et al, 2002). In fact, when rats in acute withdrawal were injected with cocaine, the DA response was blunted, and the higher the maintenance dose of heroin the greater was the blunting. Here it should be noted that, in our locomotion study (Figure 4, panel b), cocaine $(20 \mathrm{mg} /$ $\mathrm{kg}$ ) significantly enhanced locomotion in rats in acute withdrawal from the heroin. Thus, taken together, our results indicate that cocaine-induced DA activity in the Acb and cocaine-induced elevation of locomotor activity can be dissociated (Kuczenski et al, 1991). Interestingly, others have found that when the activity of the mesolimbic DA systems is tested in animals at later time points after withdrawal, repeated exposure to opioid drugs augments the DA response to electrically evoked release (Nestby et al, 1997) and to the administration of morphine (Spanagel et al, 1993). Thus, from what is known about the development of sensitization within the mesolimbic DA system (see Kalivas and Stewart, 1991), it is likely that repeated exposure to opioid drugs might lead to reduced (especially after continuous exposure) responsiveness soon after discontinuation of the treatment and to hyper-responsiveness after longer periods of withdrawal. Unfortunately, our study cannot verify this hypothesis, as the effect of cocaine on DA activity in the Acb was not tested at a later point in time after discontinuation of heroin treatment. We did, however, explore the effects of cocaine on locomotion and the voluntary intake of cocaine in animals in protracted withdrawal from heroin.

\section{Effects of Cocaine in Rats During Protracted Heroin Withdrawal}

In rats tested in protracted withdrawal from heroin, 14 days after the removal of the mini-pumps, those previously 
maintained on the highest doses of heroin showed a small, but significant, sensitized response to the locomotor stimulatory effects of a low dose of cocaine. The observation of behavioral cross-sensitization between heroin and cocaine was not surprising in light of a number of reports suggesting that pretreatment with opioid drugs sensitizes subsequent behavioral responses to a variety of DA agonists (Martin and Takemori, 1985; Vanderschuren et al, 1999), including amphetamine (Vezina et al, 1989; Cunningham and Kelley, 1992; Vanderschuren et al, 1999; Lett, 1989) and cocaine (Lett, 1989; Vanderschuren et al, 1999). Our study further suggests that the expression of cross-sensitization is dependent on the dose of the drug challenge because enhanced activity was observed only in the heroin preexposed rats that were challenged with the lower dose of cocaine (ie $5 \mathrm{mg} / \mathrm{kg}$ ).

The observation of a dose-dependent cross-sensitization between the locomotor stimulatory effects of heroin and cocaine is consistent with our finding that the reinforcing effects of cocaine also appeared to be enhanced by previous exposure to heroin. In fact, during the tests for intravenous self-administration of cocaine given 28 days after withdrawal, rats exposed to the highest heroin dose selfadministered more cocaine at the lowest dose; they also showed a small enhancement of escalation of cocaine intake over days, and a shift in the dose-response for cocaine selfadministration that was significant only at lowest dose of cocaine. These data are consistent with studies showing that pre-exposure to morphine can enhance the reinforcing effects of cocaine in a conditioned place preference procedure (Lett, 1989), and with those showing that the activating and reinforcing effects of stimulants share common neural mechanisms (Wise and Bozarth, 1987; Robinson and Berridge, 2003; Spanagel, 1995). They are also consistent with the view that differences in sensitivity to cocaine self-administration become apparent primarily when low doses are used (Deroche et al, 1999; Mantsch et al, 2001; but see Piazza et al, 2000), although it is possible that larger differences would have emerged had we tested the animals for longer periods of time during the test for escalation (Ahmed and Koob, 1999; Ahmed et al, 2000) and during the assessment of the dose-response relationship. Perhaps more importantly, the small degree of crosssensitization between the stimulant effects of heroin and cocaine in this study might have been expected owing to the fact that heroin was administered continuously via a minipump. There is ample evidence that behavioral sensitization is greatly enhanced by intermittent regimens of administration (Post, 1980; Stewart and Badiani, 1993).

\section{Effects of Chronic Continuous Exposure to Heroin and Withdrawal from Heroin}

An important and somewhat unexpected finding from the present study was the dose-dependent elevation in locomotion observed in tests given during chronic heroin exposure by osmotic mini-pumps. To our knowledge, this is the first report that chronic, continuous exposure to heroin dose dependently elevates locomotor activity, although it has been shown that acute injections of morphine and buprenorphine elevate locomotion in morphine-dependent rats (Bartoletti et al, 1985, 1987, 1993, 1999).
Another related finding is the observation of tolerance and lack of tolerance to different heroin effects observed during chronic exposure. Thus, tolerance to the depressant effects of heroin was most obvious in the animals that received the highest heroin dose (ie $14.0 \mathrm{mg} / \mathrm{kg} / \mathrm{day}$ ). In fact, in one dose-response pilot study in which we tested this dose using pumps that were not primed, we observed complete catalepsy within $5 \mathrm{~min}$ from surgery and, about 30 min later, progressive respiratory depression leading to death. Thus, in order to use this high dose of heroin in our experiments, we had to administer an opioid receptor antagonist, naloxone ( $1 \mathrm{mg} / \mathrm{kg}$, s.c.), immediately following pump implantation. This single injection readily eliminated the severe catalepsy and lethal respiratory depression (Trujillo and Akil, 1991), presumably by competing with heroin metabolites for binding at the $\mu$-opioid receptors, and allowed for the gradual development of tolerance and thus survival of the subjects. In the same rats, however, we observed no tolerance to the stimulatory effects of heroin on locomotor activity over 2 weeks of chronic exposure (see Figure 1, panels 2 and 3 ). This is a common finding observed when animals are given repeated intermittent exposure to opioids (Babbini and Davis, 1972; Joyce and Iversen, 1979; Bartoletti et al, 1985), but to our knowledge it has not been studied using continuous exposure. The present results, therefore, emphasize the known finding that different effects of opioid drugs display tolerance at different rates (Gustein and Akil, 2001) and that not all effects show tolerance, even with continuous exposure (Solomon et al, 1987; Stewart and Badiani, 1993).

Finally, it should be noted that chronic exposure to heroin via osmotic mini-pumps was effective in inducing physical dependence, something that has already been established using other opioid drugs (Adams and Holtzman, 1990; Paronis and Holtzman, 1992; Zhou et al, 1996; Thornton and Smith, 1997; Lesser et al, 1996; Houghton et al, 2001). In our study, physical dependence was inferred from the occurrence of two different types of withdrawal symptoms upon discontinuation of heroin. The first was a rapid, and dose-dependent, loss of body weight, which is a major physiological symptom of opioid withdrawal in rodents, humans, and nonhuman primates (Akera and Brody, 1968; Cicero and Meyer, 1973; van der Laan et al, 1991; Langerman et al, 2001; Wen and Ho, 1982; Wen et al, 1984; Osborn et al, 2002; Takada and Yanagita, 1997; Aceto et al, 1986; Holtzman and Villarreal, 1969, 1971, 1973). It should be noted here that chronic heroin exposure was also associated with reduced body weight gains, and that herointreated animals did not reach controls' weight levels, even after 2 drug-free weeks (see Figure 3, panel b).

The second measure of physical dependence was a depression of locomotor activity measured $24 \mathrm{~h}$ after the removal of the heroin-filled mini-pumps. It is known that locomotor activity in rats is depressed during early withdrawal from opioids (Druhan et al, 2000; Schulteis et al, 1994; van der Laan and Jansen, 1992; van der Laan et al, 1991), and our study indicates that the magnitude of depression is dependent upon the previous maintenance dose of heroin. The dose-dependent nature of the effect, and the fact that it was not evident in tests given 14 days after the removal of the pumps, clearly indicate that the decrease in locomotion resulted from acute heroin withdrawal. 
In summary, we used osmotic mini-pumps to expose rats to heroin at doses sufficiently high to induce physical dependence as measured by symptoms of withdrawal. During chronic exposure, rats displayed heightened locomotor activity that was further augmented by acute cocaine administration. This suggests that heroin-cocaine co-use might be motivated by additive interactions between these two drugs, possibly at the level of psychomotor stimulation. During acute withdrawal from heroin, cocaine reversed the dose-dependent reduction in locomotion. This suggests that heroin-cocaine co-users might sometimes employ cocaine to alleviate some symptoms of opioid withdrawal. Finally, during protracted withdrawal, the stimulatory effects of a low dose of cocaine were marginally enhanced in rats previously exposed to the higher doses of heroin, and when given the opportunity to self-administer a low dose of cocaine, these same rats self-administered greater amounts of cocaine. This suggests the possibility that a previous history of heroin dependence could enhance the effectiveness of cocaine as a stimulant and as a reinforcer.

\section{ACKNOWLEDGEMENTS}

This research was supported by an Interdisciplinary Health Research Team (IHRT) grant from the Canadian Institutes of Health Research (CIHR), and grants from the Fond de la Recherche en Santé du Québec (FRSQ), and Fond pour la Formation de Chercheurs et l'Aide à la Recherche du Québec (FCAR).

\section{REFERENCES}

Aceto MD, Dewey WL, Portoghese PS, Takemori AE (1986). Effects of beta-funaltrexamine (beta-fna) on morphine dependence in rats and monkeys. Eur J Pharmacol 123: 387-393.

Acquas E, Carboni E, Di Chiara G (1991). Profound depression of mesolimbic dopamine release after morphine withdrawal in dependent rats. Eur J Pharmacol 193: 133-134.

Acquas E, Di Chiara G (1992). Depression of mesolimbic dopamine transmission and sensitization to morphine during opiate abstinence. J Neurochem 58: 1620-1625.

Adams JU, Holtzman SG (1990). Tolerance and dependence after continuous morphine infusion from osmotic pumps measured by operant responding in rats. Psychopharmacology 100: 451-458.

Ahmed SH, Koob GF (1999). Long-lasting increase in the set point for cocaine self-administration after escalation in rats. Psychopharmacology 146: 303-312.

Ahmed SH, Walker JR, Koob GF (2000). Persistent increase in the motivation to take heroin in rats with a history of drug escalation. Neuropsychopharmacology 22: 413-421.

Akera T, Brody TM (1968). The addiction cycle to narcotics in the rat and its relation to catecholamines. Biochem Pharmacol 17: 675-688.

Babbini M, Davis WM (1972). Time-dose relationships for locomotor activity effects of morphine after acute or repeated treatment. Br J Pharmacol 46: 213-224.

Bardo MT, Rowlett JK, Harris MJ (1995). Conditioned place preference using opiate and stimulant drugs: a meta-analysis. Neurosci Biobehav Rev 19: 39-51.

Bartoletti M, Gaiardi M, Gubellini C (1999). Effects of buprenorphine on motility in morphine post-dependent rats. Pharmacol Res 40: 327-332.
Bartoletti M, Gaiardi M, Gubellini C, Bacchi A, Babbini M (1985). Cross-sensitization to the excitatory effect of morphine in postdependent rats. Neuropharmacology 24: 889-893.

Bartoletti M, Gaiardi M, Gubellini C, Bacchi A, Babbini M (1987). Previous treatment with morphine and sensitization to the excitatory actions of opiates: dose-effect relationship. Neuropharmacology 26: 115-119.

Bartoletti M, Gaiardi M, Gubellini C, Bacchi A, Babbini M (1993). Effects of buprenorphine on motility in chronically morphine treated rats. Neuropharmacology 32: 865-868.

Benswick T, Best D, Rees S, Coomber R, Gossop M, Strang J (2001). Multiple drug use: patterns and practices of heroin and crack use in a population of opiate addicts in treatment. Drug Alcohol Rev 20: 201-204.

Bickel WK, Kelly TH (1988). The relationship of stimulus control to the treatment of substance abuse. In: Ray BA (ed). Learning Factors in Substance Abuse. US Government Printing Office: Washington, DC. pp 122-140.

Blumberg H, Ikeda C (1978). Naltrexone, morphine and cocaine interactions in mice and rats. J Pharmacol Exp Ther 206: 303-310.

Broers B, Giner F, Dumont P, Mino A (2000). Inpatient opiate detoxification in geneva: follow-up at 1 and 6 months. Drug Alcohol Depend 58: 85-92.

Bux DA, Lamb RJ, Iguchi MY (1995). Cocaine use and HIV risk behavior in methadone maintenance patients. Drug Alcohol Depend 37: 29-35.

Carneiro M, Fuller C, Doherty MC, Vlahov D (1999). HIV prevalence and risk behaviors among new initiates into injection drug use over the age of 40 years old. Drug Alcohol Depend 54: 83-86.

Cicero TJ, Meyer ER (1973). Morphine pellet implantation in rats: quantitative assessment of tolerance and dependence. J Pharmacol Exp Ther 184: 404-408.

Crippens D, Robinson TE (1994). Withdrawal from morphine or amphetamine: different effects on dopamine in the ventralmedial striatum studied with microdialysis. Brain Res 650: $56-62$.

Crofts N, Louie R, Rosenthal D, Jolley D (1996). The first hit: circumstances surrounding initiation into injecting. Addiction 91: 1187-1196.

Cunningham ST, Kelley AE (1992). Evidence for opiate-dopamine cross-sensitization in nucleus accumbens: studies of conditioned reward. Brain Res Bull 29: 675-680.

Deroche V, le Moal M, Piazza PV (1999). Cocaine self-administration increases the incentive motivational properties of the drug in rats. Eur J Neurosci 11: 2731-2736.

Di Chiara G (1995). The role of dopamine in drug abuse viewed from the perspective of its role in motivation. Drug Alcohol Depend 38: 95-137.

Di Chiara G, Imperato A (1986). Preferential stimulation of dopamine release in the nucleus accumbens by opiates, alcohol, and barbiturates: studies with transcerebral dialysis in freely moving rats. Ann NY Acad Sci 473: 367-381.

Di Chiara G, Imperato A (1988). Drugs abused by humans preferentially increase synaptic dopamine concentrations in the mesolimbic system of freely moving rats. Proc Natl Acad Sci USA 85: 5274-5278.

Diaz T, Chu SY, Byers Jr RH, Hersh BS, Conti L, Rietmeijer CA et al (1994). The types of drugs used by HIV-infected injection drug users in a multistate surveillance project: implications for intervention. Am J Public Health 84: 1971-1975.

Dinwiddie SH, Cottler L, Compton W, Abdallah AB (1996). Psychopathology and HIV risk behaviors among injection drug users in and out of treatment. Drug Alcohol Depend 43: 1-11.

Doherty MC, Garfein RS, Monterroso E, Latkin C, Vlahov D (2000). Gender differences in the initiation of injection drug use among young adults. J Urban Health 77: 396-414. 
Dolan MP, Black JL, Deford HA, Skinner JR, Robinowitz R (1987). Characteristics of drug abusers that discriminate needle-sharers. Public Health Rep 102: 395-398.

Dolan MP, Black JL, Penk WE, Robinowitz R, Deford HA (2001). Predicting the outcome of contingency contracting for drug abuse. Behav Ther 17: 470-474.

Downey KK, Helmus TC, Schuster CR (2000). Treatment of heroindependent poly-drug abusers with contingency management and buprenorphine maintenance. Exp Clin Psychopharmacol 8: 176-184.

Druhan JP, Walters CL, Aston-Jones G (2000). Behavioral activation induced by $\mathrm{D}(2)$-like receptor stimulation during opiate withdrawal. J Pharmacol Exp Ther 294: 531-538.

Dunn J, Laranjeira RR (1999). Transitions in the route of cocaine administration - characteristics, direction and associated variables. Addiction 94: 813-824.

Duvauchelle CL, Sapoznik T, Kornetsky C (1998). The synergistic effects of combining cocaine and heroin ('speedball') using a progressive-ratio schedule of drug reinforcement. Pharmacol Biochem Behav 61: 297-302.

Erb S, Shaham Y, Stewart J (1998). The role of corticotropinreleasing factor and corticosterone in stress- and cocaineinduced relapse to cocaine seeking in rats. J Neurosci 18: $5529-5536$.

Freud S (1887). Craving for and fear of cocaine. In: Byck R (ed). Cocaine Papers. Stonehill: New York.

Gatch MB, Negus SS, Butelman ER, Mello NK (1995). Antinociceptive effects of cocaine/opioid combinations in rhesus monkeys. J Pharmacol Exp Ther 275: 1346-1354.

Gelkopf M, Bleich A, Hayward R, Bodner G, Adelson M (1999). Characteristics of benzodiazepine abuse in methadone maintenance treatment patients: a 1 year prospective study in an Israeli clinic. Drug Alcohol Depend 55: 63-68.

Goldstein A (1972). Heroin addiction and the role of methadone in its treatment. Arch Gen Psychiatry 26: 291-297.

Gossop M, Marsden J, Stewart D, Treacy S (2000). Routes of drug administration and multiple drug misuse: regional variations among clients seeking treatment at programmes throughout England. Addiction 95: 1197-1206.

Green-Jordan K, Warren L, Kantak KM (2001). Temporal factors affecting cocaine-opioid interactions: a cocaine drug discrimination study in rats. Psychopharmacology 156: 427-434.

Grella CE, Anglin MD, Wugalter SE (1995). Cocaine and crack use and HIV risk behaviors among high-risk methadone maintenance clients. Drug Alcohol Depend 37: 15-21.

Grella CE, Anglin MD, Wugalter SE (1997). Patterns and predictors of cocaine and crack use by clients in standard and enhanced methadone maintenance treatment. Am J Drug Alcohol Abuse 23: $15-42$.

Griffiths P, Gossop M, Powis B, Strang J (1992). Extent and nature of transitions of route among heroin addicts in treatment - preliminary data from the drug transitions study. $\mathrm{Br}$ J Addict 87: 485-491.

Grinspoon L, Bakalar JB (1976). Cocaine: A Drug and its Social Evolution. Basic Books: New York.

Gustein HB, Akil H (2001). Opioid analgesics. In: Hardman JG, Limbird LE (eds). Goodman \& Gilman's: The Pharmacological Basis of Therapeutics. McGraw-Hill: New York. pp 569-619.

Harrigan SE, Downs DA (1978). Self-administration of heroin, acetylmethadol, morphine, and methadone in rhesus monkeys. Life Sci 22: 619-623.

Hausser D, Kubler D, Dubois-Arber F (1999). Characteristics of heroin and cocaine users unknown to treatment agencies. Results from the Swiss hidden population study. Soz Praventivmed 44: 222-232.

Holtzman SG, Villarreal JE (1969). Morphine dependence and body temperature in rhesus monkeys. J Pharmacol Exp Ther 166: $125-133$.
Holtzman SG, Villarreal JE (1971). Pharmacologic analysis of the hypothermic responses of the morphine-dependent rhesus monkey. J Pharmacol Exp Ther 177: 317-325.

Holtzman SG, Villarreal JE (1973). Operant behavior in the morphine-dependent rhesus monkey. J Pharmacol Exp Ther 184: 528-541.

Houghton AK, Parsons CG, Headley PM (2001). Mrz 2/579, a fast kinetic NMDA channel blocker, reduces the development of morphine tolerance in awake rats. Pain 91: 201-207.

Hudgins R, McCusker J, Stoddard A (1995). Cocaine use and risky injection and sexual behaviors. Drug Alcohol Depend 37: 7-14.

Hunt DE, Lipton DS, Goldsmith D, Strug D (1984). Street pharmacology: uses of cocaine and heroin in the treatment of addiction. Drug Alcohol Depend 13: 375-387.

Joe GW, Simpson DD (1995). HIV risks, gender, and cocaine use among opiate users. Drug Alcohol Depend 37: 23-28.

Johnson SW, North RA (1992). Opioids excite dopamine neurons by hyperpolarization of local interneurons. J Neurosci 12: 483-488.

Joyce EM, Iversen SD (1979). The effect of morphine applied locally to mesencephalic dopamine cell bodies on spontaneous motor activity in the rat. Neurosci Lett 14: 207-212.

Kalivas PW, Stewart J (1991). Dopamine transmission in the initiation and expression of drug- and stress-induced sensitization of motor activity. Brain Res Rev 16: 223-244.

Kauppila T, Mecke E, Pertovaara A (1992). Enhancement of morphine-induced analgesia and attenuation of morphineinduced side-effects by cocaine in rats. Pharmacol Toxicol 71, t-8.

Kidorf M, Stitzer ML (1993). Descriptive analysis of cocaine use of methadone patients. Drug Alcohol Depend 32: 267-275.

Koob GF (1992). Neural mechanisms of drug reinforcement. Ann NY Acad Sci 654: 171-191.

Kosten TA (1989). Cocaine attenuates opiate withdrawal in human and rat. NIDA Res Monogr 95: 361-362.

Kosten TA (1990). Cocaine attenuates the severity of naloxoneprecipitated opioid withdrawal. Life Sci 47: 1617-1623.

Kosten TR, Rounsaville BJ, Kleber HD (1987). A 2.5-year follow-up of cocaine use among treated opioid addicts. Have our treatments helped? Arch Gen Psychiatry 44: 281-284.

Kreek MJ (1997). Opiate and cocaine addictions: challenge for pharmacotherapies. Pharmacol Biochem Behav 57: 551-569.

Kreek MJ (2000). Methadone-related opioid agonist pharmacotherapy for heroin addiction. History, recent molecular and neurochemical research and future in mainstream medicine. Ann NY Acad Sci 909: 186-216.

Kuczenski R, Segal DS, Aizenstein ML (1991). Amphetamine, cocaine, and fencamfamine: relationship between locomotor and stereotypy response profiles and caudate and accumbens dopamine dynamics. J Neurosci 11: 2703-2712.

Langerman L, Piscoun B, Bansinath $\mathrm{M}$, Shemesh $\mathrm{Y}$, Turndorf $\mathrm{H}$, Grant GJ (2001). Quantifiable dose-dependent withdrawal after morphine discontinuation in a rat model. Pharmacol Biochem Behav 68: 1-6.

Leander JD, Lucot JB (1977). Toxic interactions of stimulants, narcotics and narcotic antagonists. Res Commun Chem Pathol Pharmacol 17: 255-264.

Leri F, Bruneau J, Stewart J (2002). Understanding polydrug use: review of heroin and cocaine co-use. Addiction 98: 7-22.

Leri F, Stewart J (2001). Drug-induced reinstatement to heroin and cocaine seeking: a rodent model of relapse in polydrug use. Exp Clin Psychopharmacol 9: 297-306.

Leri F, Stewart J, Tremblay A, Bruneau J (2003). Heroin and cocaine co-use in a group of intravenous drug users in Montreal. J Psychiatry Neurosci (in press).

Lesser GJ, Grossman SA, Leong KW, Lo H, Eller S (1996). In vitro and in vivo studies of subcutaneous hydromorphone implants designed for the treatment of cancer pain. Pain 65: 265-272. 
Lett BT (1989). Repeated exposures intensify rather than diminish the rewarding effects of amphetamine, morphine, and cocaine. Psychopharmacology 98: 357-362.

Mantsch JR, Ho A, Schlussman SD, Kreek MJ (2001). Predictable individual differences in the initiation of cocaine self-administration by rats under extended-access conditions are dosedependent. Psychopharmacology 157: 31-39.

Martin JR, Takemori AE (1985). Increased sensitivity to dopamine agonists following a single dose of morphine or levorphanol in mice. Eur J Pharmacol 119: 75-84.

Mattox AJ, Thompson SS, Carroll ME (1997). Smoked heroin and cocaine base (speedball) combinations in rhesus monkeys. Exp Clin Psychopharmacol 5: 113-118.

Mello NK, Negus SS, Lukas SE, Mendelson JH, Sholar JW, Drieze J (1995). A primate model of polydrug abuse: cocaine and heroin combinations. J Pharmacol Exp Ther 274: 1325-1337.

Misra AL, Pontani RB, Vadlamani NL (1987). Stereospecific potentiation of opiate analgesia by cocaine: predominant role of noradrenaline. Pain 28: 129-138.

Nestby P, Vanderschuren LJ, De Vries TJ, Hogenboom F, Wardeh G, Mulder AH et al (1997). Ethanol, like psychostimulants and morphine, causes long-lasting hyperreactivity of dopamine and acetylcholine neurons of rat nucleus accumbens: possible role in behavioural sensitization. Psychopharmacology 133: 69-76.

Nott MW (1968). Potentiation of morphine analgesia by cocaine in mice. Eur J Pharmacol 5: 93-99.

Osborn DA, Cole MJ, Jeffery HE (2002). Opiate treatment for opiate withdrawal in newborn infants (Cochrane Review). In: The Cochrane Library, Issue 3. Oxford: update Software.

Paronis CA, Holtzman SG (1992). Development of tolerance to the analgesic activity of mu agonists after continuous infusion of morphine, meperidine or fentanyl in rats. J Pharmacol Exp Ther 262: 1-9.

Paxinos G, Watson C (1997). The Rat Brain in Stereotaxic Coordinates. Academic Press: San Diego.

Perez dlC, Trujols J, Ribalta E, Casas M (1997). Cocaine use immediately prior to entry in an inpatient heroin detoxification unit as a predictor of discharges against medical advice. $A m \mathrm{~J}$ Drug Alcohol Abuse 23: 267-279.

Piazza PV, Deroche-Gamonent V, Rouge-Pont F, le Moal M (2000). Vertical shifts in self-administration dose-response functions predict a drug-vulnerable phenotype predisposed to addiction. J Neurosci 20: 4226-4232.

Plunkett LM, Seifen E, Kennedy RH (1989). Effects of morphine pretreatment on cocaine cardiotoxicity in anesthetized guineapigs. Arch Int Pharmacodyn Ther 297: 60-67.

Post RM (1980). Intermittent versus continuous stimulation: effect of time interval on the development of sensitization or tolerance. Life Sci 26: 1275-1282.

Ranaldi R, Munn E (1998). Polydrug self-administration in rats: cocaine-heroin is more rewarding than cocaine-alone. Neuroreport 9: 2463-2466.

Robbins TW, Everitt BJ (1999). Drug addiction: bad habits add up. Nature 398: $570-657$.

Robinson TE, Berridge KC (2003). Addiction. Annu Rev Psychol 54: 25-53.

Rowlett JK, Negus SS, Shippenberg TS, Mello NK, Walsh SL, Spealman RD (1997). Combined cocaine and opioid abuse: from neurobiology to the clinic. NIDA Res Monogr 178: 55-57.

Rowlett JK, Woolverton WL (1997). Self-administration of cocaine and heroin combinations by rhesus monkeys responding under a progressive-ratio schedule. Psychopharmacology 133: 363-371.

Schottenfeld RS, O'Malley S, Abdul-Salaam K, O'Connor PG (1993). Decline in intravenous drug use among treatmentseeking opiate users. J Subst Abuse Treat 10: 5-10.

Schulteis G, Markou A, Gold LH, Stinus L, Koob GF (1994). Relative sensitivity to naloxone of multiple indices of opiate withdrawal: a quantitative dose-response analysis. J Pharmacol Exp Ther 271: 1391-1398.

Schutz CG, Vlahov D, Anthony JC, Graham NM (1994). Comparison of self-reported injection frequencies for past 30 days and 6 months among intravenous drug users. J Clin Epidemiol 47: 191-195.

Shimada A, Tsuda T, Yanagita T (1988). Mode of potentiating action of cocaine in morphine analgesia. Jpn J Pharmacol 48: 185-193.

Sierra V, Duttaroy A, Lutfy K, Candido J, Billings B, Zito SW et al (1992). Potentiation of opioid analgesia by cocaine: the role of spinal and supraspinal receptors. Life Sci 50: 591-597.

Solomon RE, Wasserman EA, Gebhart GF (1987). Tolerance to antinociceptive effects of morphine without tolerance to its effects on schedule-controlled behavior. Psychopharmacology 92: 327-333.

Spanagel R (1995). Modulation of drug-induced sensitization processes by endogenous opioid systems. Behav Brain Res 70: 37-49.

Spanagel R, Almeida OF, Bartl C, Shippenberg TS (1994). Endogenous kappa-opioid systems in opiate withdrawal: role in aversion and accompanying changes in mesolimbic dopamine release. Psychopharmacology 115: 121-127.

Spanagel R, Almeida OF, Shippenberg TS (1993). Long lasting changes in morphine-induced mesolimbic dopamine release after chronic morphine exposure. Synapse 14: 243-245.

Stewart J, Badiani A (1993). Tolerance and sensitization to the behavioral effects of drugs. Behav Pharmacol 4: 289-312.

Strug DL, Hunt DE, Goldsmith DS, Lipton DS, Spunt B (1985). Patterns of cocaine use among methadone clients. Int J Addict 20: $1163-1175$.

Suzuki T, Mori T, Tsuji M, Maeda J, Kishimoto Y, Misawa M et al (1997). Differential effects of mu-, delta- and kappa-opioid receptor agonists on the discriminative stimulus properties of cocaine in rats. Eur J Pharmacol 324: 21-29.

Takada K, Yanagita T (1997). Drug dependence study on vigabatrin in rhesus monkeys and rats. Arzneimittelforschung 47: 1087-1092.

Thornton SR, Smith FL (1997). Characterization of neonatal rat fentanyl tolerance and dependence. J Pharmacol Exp Ther 281: 514-521.

Torrens M, San L, Peri JM, Olle JM (1991). Cocaine abuse among heroin addicts in Spain. Drug Alcohol Depend 27: 29-34.

Trujillo KA, Akil H (1991). The NMDA receptor antagonist mk-801 increases morphine catalepsy and lethality. Pharmacol Biochem Behav 38: 673-675.

van der Laan JW, Jansen van't Land C (1992). Chronic infusion of clonidine does not alleviate spontaneous morphine withdrawal symptoms in rats. Psychopharmacology 108: 283-288.

van der Laan JW, Jansen van't Land C, Loeber JG, de Groot G (1991). Validation of spontaneous morphine withdrawal symptoms in rats. Arch Int Pharmacodyn Ther 311: 32-45.

van Ree JM, Slangen JL, de Wied D (1978). Intravenous selfadministration of drugs in rats. J Pharmacol Exp Ther 204: 547-557.

Vanderschuren LJ, Schoffelmeer AN, Mulder AH, De Vries TJ (1999). Dopaminergic mechanisms mediating the long-term expression of locomotor sensitization following pre-exposure to morphine or amphetamine. Psychopharmacology 143: 244-253.

Vezina P, Giovino AA, Wise RA, Stewart J (1989). Environmentspecific cross-sensitization between the locomotor activating effects of morphine and amphetamine. Pharmacol Biochem Behav 32: 581-584.

Volkow ND, Fowler JS, Wang GJ, Ding YS, Gatley SJ (2002). Role of dopamine in the therapeutic and reinforcing effects of methylphenidate in humans: results from imaging studies. Eur Neuropsychopharmacol 12: 557-566. 
Wang NS, Brown VL, Grabowski J, Meisch RA (2001). Reinforcement by orally delivered methadone, cocaine, and methadonecocaine combinations in rhesus monkeys: are the combinations better reinforcers? Psychopharmacology 156: 63-72.

Wen HL, Ho WK (1982). Suppression of withdrawal symptoms by dynorphin in heroin addicts. Eur J Pharmacol 82: 183-186.

Wen HL, Ho WK, Wen PY (1984). Comparison of the effectiveness of different opioid peptides in suppressing heroin withdrawal. Eur J Pharmacol 100: 155-162.
Wise RA, Bozarth MA (1987). A psychomotor stimulant theory of addiction. Psychol Rev 94: 469-492.

Worley CM, Valadez A, Schenk S (1994). Reinstatement of extinguished cocaine-taking behavior by cocaine and caffeine. Pharmacol Biochem Behav 48: 217-221.

Zhou Y, Spangler R, Maggos CE, LaForge KS, Ho A, Kreek MJ (1996). Steady-state methadone in rats does not change mrna levels of corticotropin-releasing factor, its pituitary receptor or pro opiomelanocortin. Eur J Pharmacol 315: 31-35. 